\title{
EFEITO DA INGESTÃO DE DERIVADOS DE SOJA (Glycine max) SOBRE A TIREÓIDE DE RATOS
}

ESTUDO COM O EMPREGO DE IODO RADIOATIVO

\begin{abstract}
Trabalho experimental apresentado à Faculdade de Ciências Farmacêuticas da Universidade de São Paulo para obtenção do grau de Mestre, em Ciência dos Alimentos.
\end{abstract}

ORIENTADOR:

PROF. DR. FRANCO M. LAJOLO 


\begin{tabular}{|c|c|c|c|}
\hline påg。 & Iinha & onde se $1 \hat{e}$ & $1 \tilde{e}-s e$ \\
\hline 5 & 5 & 2.5-vini $1-2-t i 00 \times a 2011$ don & I. 5-vini 1-2 wtiooxacolidona \\
\hline 9 & 26 & cetraiodotitonins & Sritiodotironing \\
\hline 10 & 2 & Serraiodotironina & Sritodotiroming \\
\hline 21 & 3 & un & \pm \\
\hline 25 & 18 & de lodotirosina & disodocijrosing \\
\hline 25 & 28 & cetrajodotzronina & sripodstroning \\
\hline 35 & 10 & $\&$ & 3 \\
\hline 56 & 6 & 292 & 263 \\
\hline 83 & 12 & persajodotironing & Exidodotín \\
\hline 83 & 13 & difadotizoning & 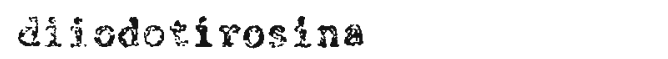 \\
\hline
\end{tabular}


Ao Prof.Dr.Franco M. Lajolo, pela eficiente orienta ção, dedicação e interesse com que acompanhou nossos trabalhos e pelos valiosos conhecimentos transmitidos; a Profa.Dra M.A.Pourchet Campos, pelo apoio recebido no Curso de Pós-Graduação em Ciência dos Alimentos; à Coordenadoria do Aperfeiçoamento de Pessoal do Nível Superior - CAPES, pela concessão de bolsa de estudos durante os anos de 1973 e 1974; ao Prof. Dr. José Carlos Barbério pela colaboração na realização de nossas anälises e pelas sugestões apresentadas; ao Instituto de Energia Atômica, na pessoa de seu superintendente Prof.Dr. Rômulo Ribeiro Pieroni, pela concessão de bolsa de estudos durante $O$ ano de 1975, e pelas facilidades concedidas na conclusão deste trabalho; à Dra. Constância P.G. da Silva pelo apoio e incentivo prestados; à Elisabeth Garcia, Flävio Fi nardi Filho e João da Penha pelos auxílios técnicos prestados; à Silia M. E. Filisetti pela realização dos gráficos; à biblio tecária Lêda Maria Brunelli da Biblicteca do Conjunto das Quí micas da USP, pela revisão e normalização das referências bibliográficas; aos nossos pais e amigos pelo apoio, coragem e confiarı̧a que sempre nos transmitiram; aos demais professo res do Departamento de Alimentos e Nutrição Experimental da Faculdade de Ciências Farmacêuticas da USP pelos conhecimen tos transmitidos e tambëm aos funcionärios e colegas que sempre colaboraram conosco, 
SUMARIO

päg.

1 INTRODUÇAO $\ldots \ldots \ldots \ldots \ldots \ldots \ldots \ldots \ldots \ldots \ldots \ldots \ldots \ldots \ldots$

2 obJETIVOS ............................. 4

3 REVISAO DA LITERATURA ................... 5

4 PLANEJAMENTO EXPERIMENTAL .................. 1 I

4.1 Fracionamento da soja................... II

4.2 Ensaios Agudos ............................. II

4.3 Ensaios Semicrônicos ..................... II

4.4 Testes Físico-Químicos .................. 13

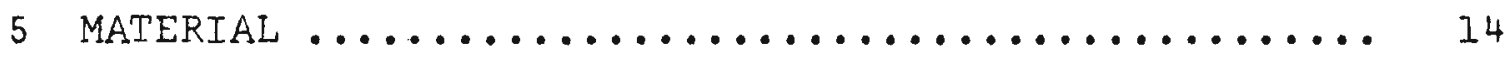

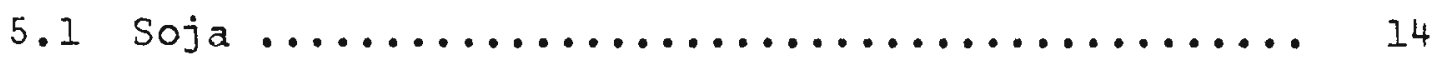

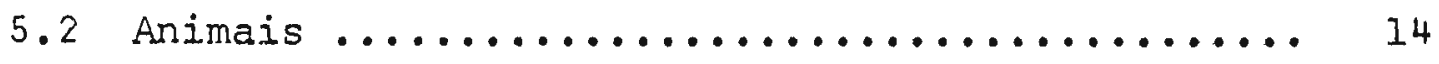

5.3 Rações Experimentais ................... 15

5.4 Iodo Radioativo ...................... 15

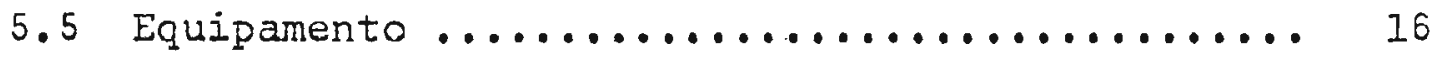

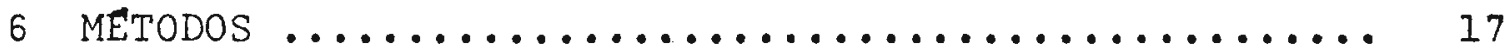

6.I Fracionamento da Farinha de Soja Desengordurada e dos Produtos Comerciais .................

6.1.1 Obtenção do Extrato Total, Extrato Bruto e Residuo ......................... 17

6.1.2 Fracionamento com etanol ............ 19

6.1.3 Purificação por peneira molecular ..... 20

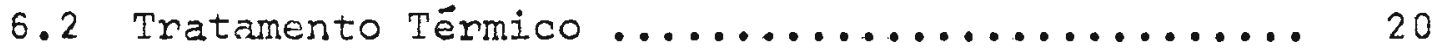

6.3 Ensaios das Frações Obtidas ............... 22

6.3 .1 Ensaios agudos ................... 22

6.3.2 Ensaios semicrônicos ............... 22 
päg.

6.4 Determinação da Poncentagem de Captação ....... 23

6.5 Doseamento dos Hormônios da Tireóide ......... 24

6.5.I Preparo do hidrolisado.............. 24

6.5 .2 Separação dos hormônios ............. 24

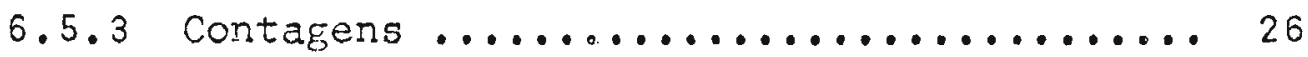

6.6 Doseamento dos Hormônios Séricos ............. 29

6.6 .1 obtenção do soro .................. 29

6.6.2 Medida indireta da função tireoidiana ... 29

6.6 .3 Radioimunoensaio .................. 29

6.7 Testes Preliminares para Identificação dos Com postos Presentes no Extrato Total e em suas Fra-

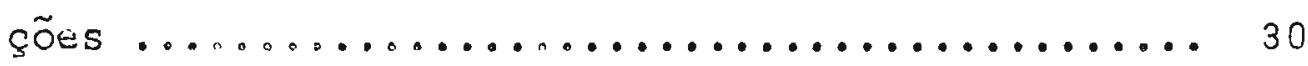

6.7 .1 Espectros de absorção .............. 30

6.7 .2 Glicides solüveis em ägua ........... 30

6.7 .3 Grupo a-amínico livre .............. 30

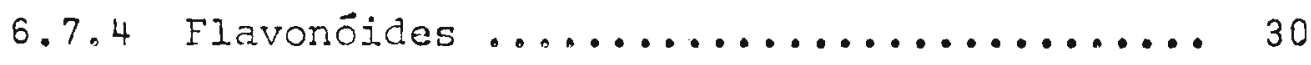

6.8 Mëtodos Estatisticos..................... 31

7 RESULTADOS E DISCUSSAO .................... 33

7.1 Ensaios Agudos Realizados com os Extratos de Farinha de Soja Desengordurada ...............

7.1.1 Efeito do extrato total não autoclavado. Ação em 24 horas .................... 33

7.1.2 Efeito do extrato total não autoclavado. Ação em 3 a 24 horas ................... 35

7.1.3 Efeito da autoclavagem sobre a ação do Ex trato Total. Ação em 24 horas .........

7.1.4 Efeito da autoclavagem sobre a ação do Ex trato Total. Ação em 6 horas ......... 41

7.2 Ensaios Agudos dos Produtos obtidos por Fracióna

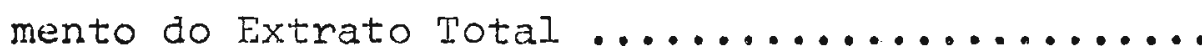


pảg.

7.3 Testes Físico-Químicos de Identificação ....... 54

7.4 Presença do Fator em Diferentes Produtos Comer ciais de soja ........................ 59

7.5 Ensaios Semicrônicos .................... 61

8 CONCLUSUES ............................. 73

9 REFERENCIAS BIBIIOGRAFICAS ................. 74

10 SUMMARY $\ldots \ldots \ldots \ldots \ldots \ldots \ldots \ldots \ldots \ldots \ldots \ldots \ldots \ldots \ldots \ldots \ldots \ldots \ldots$

11 IISTA DE TABELAS E FIGURAS .................. 84 
1 INTRODUÇÃO

A possibilidade da alimentação adequada das populações atuais e futuras, reside no contínuo diagnóstico e busca de soluções para problemas complexos e multi-setoriais, relativos co suprimento, demanda e utilização biológica dos alimentos. Ambos permitirão trazer alternativas, apontar prioridades, para um planejamento nutricional associado ao planejamen to geral da saúde e ao desenvolvimento sócio-econômico do país.

- E sabido que a ingestão dos alimentos está intimamente associada ao seu custo, o que torna muito importante a otimização da utilização biológica dos nutrientes veiculados, espe cialmente se pensarmos em termos de populações confrontadas com potenciais alimentares existentes. Por exemplo, na Améri ca Latina, $7 \%$ dos alimentos consumidos seriam suficientes para aliviar a desnutrição dos grupos populacionais vulneráveis existentes, mostrando a importância de, mesmo pequenas perdas serem reduzidas, o que em última análise, corresponderia a um aumento na eficiência da produção agrícola.

- Ao nível da utilização biológica dos alimentos, sabemos que os nutrientes devem estar "disponíveis", não deve ha ver fatores tóxicos presentes e, o preparo e o processamen to devem sor adequados. 
Um importante grupo de alimentos vegetais, o das Leguminosas, apresenta uma série de problemas de natureza bioquími ca, que reduzem a possibilidade de sua utilização biológica co mo a presença de fatores tóxicos naturais e a baixa digestibilidade de sua proteína. Por essa razão, especialmente, quando se trata de novos alimentos, ou mesmo do aumento e diversificação na utilização de produtos antas pouco consumidos, faz-se necessäria uma anälise detalhada de suas qualidades. A so ja e seus produtos enquadram-se nessa situação.

Originalmente consumida "in natura", nos ültimos anos passou a constituin uma das fontes semi-convencionais de alimentos, e a ser adicionada a outros produtos com finalidade tecnológica ou de complementação nutricional, na forma de concentrados e isolados protéicos, e de "leites artificiais", tanto em programas oficiais de alimentação de grupos vilnerä veis, como pela empresa privada.

- Resultados obtidos em nossos laboratónios e informações de outros, envolvidos como nôs, no estudo de produtos processa dos de soja, acusaram para esses alimentos um valor biológico inferior ao previsivel; o fato é agravado ainda pela possibilidade da existência de lesōes bioquímicas, não eviden ciáveis nos testes de crescimentos como normalmente efetuados.

Essas considerações e as suas implicações mostram a importância do conhecimento detalhado sobre a existência de possiveis compostos com alguma ação biológica.

- Resolvemos com esse espírito buscar mais informações so bre esses fatores, estudando um que parece agir na tireóide, cuja existência foi relatada há tempo, mas sobre o qual pouco 
se sabe em termos de natureza, mecanismo de ação e significado da ação biológica.

Esperamos, assim, contribuir ao nivel cientifico, para a otimização da utilização dos nossos potenciais alimentares, participando ao lado de elementos da nossa e de outras áreas na tentativa de trazer dados que abram alternativas para a solução dos problemas alimentares e nutricionais. 
.4 .

Os objetivos especificos do presente trabalho foram es tudar, numa variedade brasileira de soja e em alguns de seus produtos comerciais, a possivel presença de fatores com ação sobre a tireóide, bem como obter informações sobre a slia natureza e mecanismo de ação. 
Substâncias que agem direta ou indiretamente na tireöide podem ser encontradas em inümeros vegetais $(10)(11)(48)$ (54)(58) e são do natureza química diversa.

Nas plantas do gênero Brassica, como couve, repolho, nabo, encontra-se a L $_{\text {,5-vinil-2-tiooxazolidona }}{ }^{(2)}$, substância capar de desencadear hiperplasia da tireóide, especialmente em condições de baixa ingestão de iodo na dieta ${ }^{(58)}$. Essa sứs tância existe na forma de um tioglicosideo inativo, precursor, que por ação de uma glicosidase, a mirosinase, é transformada na substância ativa(11). A enzima também é produzida por bac têrias intestinais que passam a ser as responsäveis pela trans formação do tioglicosídeo quando o produto foi cozido e a enzi ma vegetal inativada(3I).

Outras tiooxazolidonas como a 5,5-dimetil-2-tiooxazolidona(1)(13), além de nitrilas como a 3-indol-acetonitrila podem ser encontradass $(6)(54)$ em plantas desse gênero, ao lado de tiocianatos, isotiocianatos e polissulfetos $(32)(48)$ (58)

Na mandioca existem dois glicosideos: a linamarina e a loto-australina, capazes de liberar cianeto pela ação de outra $\beta$-glicosidase, a linamarase; o cianeto por sua vez é detoxificado pela ação da rodanase hepática a tiocianato, sưbs 
tância tambëm bociogênica(17).

Nas cebolas, tambëm, encontram-se compostos sulfurados capazes de bloquear a captação de iodo pela tireöide, como o n-propildissulfeto que já foi responsabilizado pela alta incidência de bócio em regiões do Libano(36).

Estudos feitos em ratos que ingeriam um pigmento gli cosídico extraído da casca do amendoim e de sementes de caju, demonstraram a existência de atividade bociogênica(29). A ação na tireóide, no caso, seria devida a uma iodação preferencial dos metabólitos formados apōs a ingestão, diminuindo assim a quantidade de iodo disponível para ligar-se à tirosina. Através desse mesmo mecanismo e, ainda, pela inibição da condensação oxidativa da monoiodotirosina (MIT) e diiodotirosina (DIT) alguns autores explicam a ação na tireóide de certos flavonóides e de seus produtos de degradação(18).

E importante citar, tambêm, os nitritos e nitratos presentes em certos vegetais $(54)$ (57) que em quantidades elevadas podem interferir diretamente na captação de iodo pela tireóide, bem como os salicilatos ${ }^{(55)}$, capazes de bloquear a ligação dos hormônios tireoideanos com as proteínas plasmáti cas e de inibir a sua formação "in vitro".

São conhecidas, ainda, substâncias como as encontra das em nozes capazes de produzir bócio de forma indireta, ou seja provocando um aumento na perda fecal de tiroxina ${ }^{(25)}$.

Ao lado dessas substâncias bociogênicas conhecidas exis tem outras cuja natureza e ação não estã caracterizada como é o caso do "fator" existente na soja (Glycine max).

A revisão da literatura mostrou que os vãrios pesqui 
sadores atribuem a causas diversas, os diferentes efeitos cau sados pela ingestão de soja sobre a tireóide, senco que alguns negam mesmo a existência de qualquer ação direta. Assim, como veremos, certos autores, observando a instalação de bōcio em ratos alimentados com soja atribuiram-no a uma possível defici ência de iodo na dieta e ao passo que outros, simplesmente, ao baixo valor biológico da proteína.

MCCARRISON ${ }^{(27)}$ foi o primeiro a relatar que ratos alimentados com soja crua apresentavam uma hiperplasia da tireóide, observável mesmo quando a ração continha teor de iodo bem superior ao necessário.

- Estudos posteriores de SHARPLESS e col. (44), WILGUS e col. (53) e HALVERSON e col. (12) demonstraram que em ratos e tambēm galinhas, a inclusão de soja não processada na ração, era capaz de provocar um aumento da glândula e que essa proprie dade era inibida, totalmente, pela administração de quantidades elevadas de iodo, ou parcialmente, pelo tratamento térmico da soja.

E interessante enfatizar aqui, que segundo WILGUS e col. (53) a adição de iodo corrigia o bócio, mas não era capaz de melhorar a diminuição de crescimento pelos animais em questão.

- Com relação à solubilidade do fator ativo, os autores citados observaram, que a propriedade bociogênica da soja crua não podia ser removida pelo tratamento com solventes orgâa nicos como ëter, acetona, clorofónmio ou etanol, com exceção de SHARPLESS e col. $(44)$ segundo os quais essa propriedade podia ser parcialmente eliminada por tratamento com ëter ou ace- 
tona.

Tambëm BLOCK e col. (4), constataram possibilidade se melhante, ou seja a de redução na capacidade bociogênica, em ratos, por desengorduramento da soja crua, apesar da soja nesse caso mostrar-se mais rica em iodo.

Efeitos semelhantes, medidos porém pela redução na cap tação de iodo radioativo, foram observadas tanto em ratos como em crianças alêrgicas ${ }^{(50)}$, alimentadas com "leite do soja". O mesmo autor observou, agora em adultos, que entre catorze testados, apenas dois manifestavam efeitos bociogênicos quando alimentados com "leite de soja" por cinco dias, sugerindo que o agente em questão, interfere com a síntese dos hormônios tireoidiaros de acordo com a suscetibilidade individual.

Por outro lado, opostamente, outros autores observaram um aumento na captação de iodo marcado tanto em ratos $(3)(49)$ co mo en crianças alimentadas com produtos derivados de soja (33)(45); esses efeitos foram atribuidos pelos pesquisadores a uma ação indiretal haveria um aumento na excreção fecal de ti roxina endógena, diminuindo o rendimento recuperador pela circulação entero-hepática, o que causaria queda da tiroxina plas mática, estimulando a produção de tireotrofina e logo causando un hipertireoidismo.

A perda fecal de tiroxina, por outro lado, seria devida a mudanças do ambiente gastro-intestinal $(3)(15)$ como: transito gastro-intestinal acelerado por causa do volume do bolo fe cal, provocando redução na reabsorção de tiroxina ou à presença de uma substância capaz de agir nessa reabsorção ou mesmo a ação de inibicores trípticos. E possível, tambēm, que a so- 
ja facilite o desenvolvimento da Escherichia coli no trato intestinal, microrganismo que consegue se ligar à tiroxina redu zindo sua reabsorção(37).

Outra linha de observação é a trazida pelas pesquisas de NORDSIEK ${ }^{(30)}$, que verificou haver um aumento de peso da tireōide, em ratos alimentados com rações contendo de 35 a $60 \%$ de soja crua, observando, porém, que a adição de caseina à ração eliminava o efeito. 0 autor sugere que, sendo a caseína uma proteina de elevado valor biolögico, pode favorecer a sin tese de proteinas e consequentemente auxiliar no transporte hu moral e na absorção intestinal dos hormônios da tireóide. Sugere, tambẻm, que esse efeito bociogênico poderia estar réla cionado com a presença de antitripsinas, hipótese levantada, também, por outros pesquisadores ${ }^{(9)}$.

Recentemente, KONIJN e col. (19) conseguiram resultados interessantes; constataram a presença de um agente depressor da função tireoidiana na farinha de soja não aquecida, que resiste à digestão pancreática e ao aquecimento em banho-maria fervente, durante duas horas, mas, è aparentemente destruido pelo tostamento da farinha.

A substância responsāvel foi parcialmente purificada pa recendo ser um oligopeptidio de baixo peso molecular ${ }^{(20)}$.

Ela consegue inibir a captação de iodo pela tireóide tanto "in vivo" (ensaios de $24 \mathrm{~h}$ ) como "in vitro" diminuindo a sua organificação $e$, quando incorporada na dieta, aumenta a cá pacidade de ligação das proteínas séricas à iodotironina $\left(T_{3}\right)$ radioativa exôgena.

A glânciula quando exposta "in vitro" ao agente depres 
sor, apresenta uma incorporação menor de radioido na forma de diiodotirosina (DIT) e a relação TRi iodotironina/tiroxina $\left(\mathrm{T}_{3} / \mathrm{T}_{4}\right)$ torna-se maior, faltam porém estudos "in vivo", para confirmar esses resultados.

Resumindo, constata-se que segundo alguns, a soja causa hipertireoidismo e segundo outros hipotireoidismo, havendo inclusive idéias diferentes com relação às propriedades quími cas da substância responsävel. Ao lado desses existem ainda outros autores $^{(46)}$ que negam a existência de qualquer ação.

Essas observações reforçam, a nosso ver, a necessidade de se fazerem mais estudos sobre o assunto, justificando os objetivos propostos. 
4 PLANEJAMENTO EXPERIMENTAL

4.1 Fracionamento da Soja

A soja foi fracionada de vârias maneiras para o isolamento do fator ativo.

\subsection{Ensaios Agudos}

As experiências dos ensaios agudos foram realizadas num periodo experimental de 3 a 24 horas. Os produtos testados (Figura 1) nos animais provinham do fracionamento da Faninha de Soja Desengordurada (FSD), Farinha de Soja Desengordurada e Autoclavada (FSDA) e Produtos Comerciais de Soja.

\subsection{Ensaios Semicrônicos}

Foram realizados dois ensaios semicrônicos; no primeiro ensaio semicrônico os animais foram submetidos a um período experimental de 16 dias e no segundo ensaio semicrônico de 29 
dias. Os produtos testados provinham do fracionamento da Farinha de Soja Desengordurada não autoclavada (FSD) e Autoclavada (FSDA) (Figura 1). Os grupos recebiam rações que conti nham produtos de fracionamento conforme indicados na Tabela I.

TABELA I - Grupos experimentais dos ensaios semicrônicos: fra ções de soja testadas.

\begin{tabular}{|c|c|c|}
\hline Ensaios & Grupos & Fração Testada \\
\hline \multirow{6}{*}{19} & FSD & $\begin{array}{l}\text { Farinha de Soja Desengordurada e não au } \\
\text { toclavad? }\end{array}$ \\
\hline & $\mathrm{R}$ & Resíduo não autoclavado \\
\hline & $R A+E B$ & $\begin{array}{l}\text { Resíduo Autoclavado + Extrato Bruto não } \\
\text { autoclavado }\end{array}$ \\
\hline & FSDA & $\begin{array}{l}\text { Farinha de Soja Desengordurada e Autocla } \\
\text { vada }\end{array}$ \\
\hline & RA & Residuo Autoclavado \\
\hline & $R \Delta+E B A$ & $\begin{array}{l}\text { Residuo Autoclavado + Extrato Bruto Auto } \\
\text { clavado }\end{array}$ \\
\hline \multirow{3}{*}{$2 \%$} & ESDA & $\begin{array}{l}\text { Farinha de Soja Desengordurada e Autocla } \\
\text { vada }\end{array}$ \\
\hline & RA & Resíduo Autoclavado \\
\hline & $R A+E B A$ & $\begin{array}{l}\text { Residuo Autoclavado + Extrato Bruto Auto } \\
\text { clavado. }\end{array}$ \\
\hline
\end{tabular}


4.4 Testes Físico-Químicos

Estes testes foram realizados em frações parcialmente purificadas que continham o fator em estudo, no sentido de verificarmos a presença em sua estrutura química de peptidios, glícides e flavonóides. 
5 MATERIAL

5.1 Soja

Utilizamos a variedade Santa Rosa, (Glycine max) obtida na Estação Experimental da Escola Superior de Agronomia de Lavras. Os derivados de soja (leite, concentrado protéico e farinha tostada) foram obtidos no comércio lo cal.

\subsection{Animais}

Foram ratos (Rattus norvegicus variedade Albinus) obtidos de colônias mantidas no biotério da Faculdade de Ciências Farmacêuticas da USP e alimentados com uma ração comercial padrão do biotério. Durante a experiência foram alojados em gaiolas individuais, recebendo ägua "ad libitum" e os diferentes tipos de rações experimentais conforme o caso. 


\subsection{Rações Experimentais}

Foram preparadas para realização dos ensaios semicrônicos.

As preparações a serem testadas foram adicionadas a uma dieta bâsica que continha 18 de mistura vitaminica, 48 de mistura salina, $8 \%$ de b́leo de soja e $87 \%$ de amido. A ádi ção das diversas fraçōes era feita às expensas de amido de for ma a resultar numa porcentagem final de $18 \%$ de proteina. As rações do segundo ensaio receberam ainda 0,28 de metionina.

A mistura salina usada no primeiro ensaio foi a de FOX \& BRIGGS ${ }^{(8)}$; $j a \vec{a}$, no segundo, alterou-se a quantidade de iodeto de potåssio de $17,0 \mathrm{mg}$ para $3,1 \mathrm{mg} 8$.

A mistura vitaminica foi descrita anteriormente ${ }^{(21)}$.

A porcentagem de proteina das rações experimentais obtida por análise ${ }^{(14)}$ encontra-se na Tabela II.

\subsection{Iodo Radioativo}

Usou-se iodeto de sódio ( $\left.\mathrm{Na}^{13 I} \mathrm{I}\right)$ dissolvido em solução fisiológica isento de carregador e de redutor.

0 iodeto de södio ( $\mathrm{Na}^{125} \mathrm{I}$ ) para a dosagem dos hormônios séricos provinha de conjuntos especificamente preparados para a sua dosagem (Lepetit S.A e Bio-Rad Laboratories). 
$\begin{aligned} & \text { TABELA II - } \text { Teor de proteína das rações utilizadas nos errsa } \\ & \text { ios semicrônicos }\end{aligned}$

\begin{tabular}{clc}
\hline Ensaios & Grupos* & proteina $(\mathrm{N} \times 6,25)$ \\
\hline & FSD & 18,71 \\
R & RA + EB & 19,12 \\
& FSDA & 18,42 \\
& RA & 18,29 \\
& RA + EBA & 18,56 \\
& & 19,72 \\
& FSDA & \\
20 & RA & 19,39 \\
& RA + EBA & 18,34 \\
* Taber I & 17,83
\end{tabular}

5.5 Equipamento

Alëm do equipamento convencional de laboratório, usou-se para as contagens um detector de cintilação, com cris tal de poço de iodeto de sódio ativado com tälio NaI(TI),e contador modelo Ultra Scaler II (Nuclear Chicago); um espectrofotômetro Acta III (Beckman) foi usado para a obtenção dos espectros de absorção no ultravioleta (UV). 
6 METODOS

6.1 Fracionamento da Farinha de Soja Desengordurada (FSD) e dos Produtos Comerciais

6.1.1 Obtenção do Extrato Total (ET), Extrato Bruto (EB) e Residuo ( $R$ )

A soja, previamente moída e desengordurada com hexana, na proporção de $1: 3$ (soja:solvente) foi tratada ainda com ëter etílico, em extrator de Soxhlet, atë desengorduramento total. A Farinha de Soja Desengordurada (FSD) assim obtida, apōs secagem ao ar, foi novamente triturada em moinho de facas e submetida a extração com ägua. A seguir, foi tratada como sugerido por KONIJN e col. (19), com as modificações descritas abaixo e esquematizadas na Figura 1. $200 \mathrm{~g}$ de FSD foram tratadas com 1,5 I de água destilla da, acidificadas com $\mathrm{HCl} I \mathrm{~N}$ atē $\mathrm{pH}$ 4,2 (ponto isoelétrico das proteínas de soja), submetidas à agitação por 1 hora, sendo a seguir, a suspensão filtrada ou centrifugada a 7.000 r.p.m. 0 precipitado foi reextraído com $500 \mathrm{ml}$ de água destilada da mesma forma e o sobrenadante resultante acrescentado ao anterior.

Os sobrenadantes conforme o caso ou eram concentra dos em evaporador rotatório a vấcuo a $50^{\circ} \mathrm{C}$ até volume final 


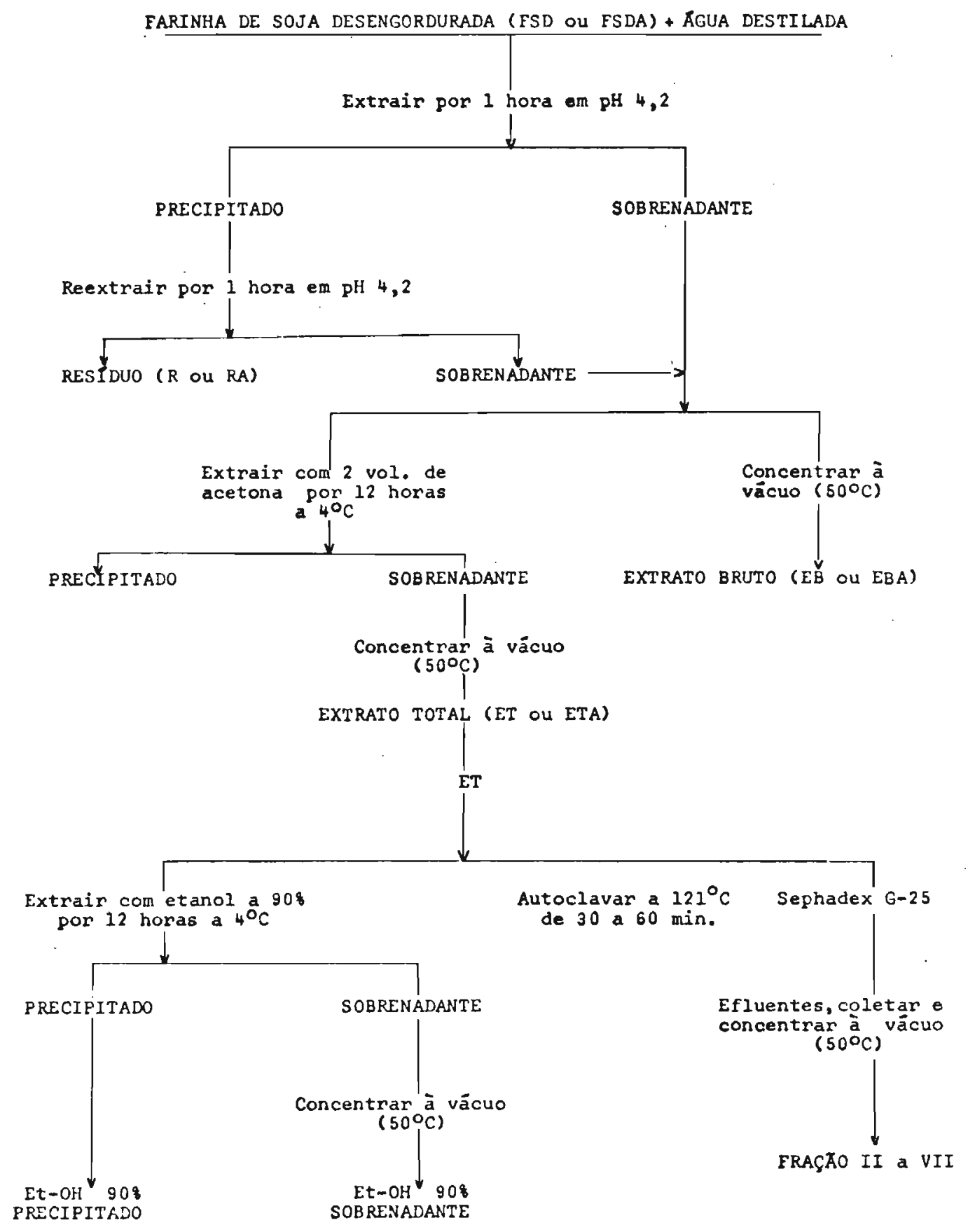

FIGURA 1: Esquema geral de fracionamento da Farinha de Soja Desengordurada 
de $100 \mathrm{ml}$ - originando O Extrato Bruto (EB) ou eram tratados com acetona na proporção de dois volumes de acetona para um volume de sobrenadante.

Apôs repouso, a $4^{\circ} \mathrm{C}$ durante doze horas, o extrato cetônico era filtrado e o filtrado concentrado em evaporador ro tatório a vácuo $\left(50^{\circ} \mathrm{C}\right)$, até volume de $100 \mathrm{ml}$, obtendo-se assim - Oxtrato Total (ET).

Para 019 teste semícrónico partimos de $1,7 \mathrm{Kg}$ de FSD e $1,7 \mathrm{Kg}$ de FSDA; para $02 \%$ teste semicrônico úa mos $4,0 \mathrm{~kg}$ de FSDA, seguindo-se o mesmo esquema tendo sido porém obtido nesse caso no Instituto de Tecnologia de Alimentos de Campinas.

A obtenção dos extratos dos Produtos Comerciais seguem $\circ$ mesmo esquema da Figura 1 até a obtenção do Extrato To tal (ET). O leite de soja sofreu prévio desengorduramento igual ao da soja moída.

\subsubsection{Fracionamento com etanol}

- Extrato Total foi adicionado de etanol até concen tração de $90 \%$, deixado em repouso a $4^{\circ} \mathrm{C}$ por doze horas e filtrado. O sobrenadante foi concentrado a $50^{\circ} \mathrm{C} \mathrm{em}$ evaporador rotatónio a văcuo ate $\circ$ volume inicialmente utilizado de Ex trato Total. Para os testes o precipitado era redissolvido em água até volume igual ao do Extrato Total (Figura 1). 
6.1.3 Purificação por peneira molecular

De 6 a $10 \mathrm{ml}$ do Extrato Total eram fracionados em coIuna de Sephadex G-25 médio ou fino $(2,0 \times 96,0 \mathrm{~cm})$, previa mente equilibrada com acetato de amônfo $0,02 \mathrm{M}$ (com velocidade de escoamento de $\cong 1,7 \mathrm{ml} / \mathrm{min}$.$) . A coluna foi eluida com ace$ tato de amônio $0,02 \mathrm{M}$, coletando-se volumes de $5 \mathrm{ml}$.

Para os testes com animais, os efluentes compreendendo cada uma das värias frações obtidas, foram reunidos e concentrados em evaporador rotatório à $50^{\circ} \mathrm{C}$ até volume igual ao introduzido na coluna.

Para obtenção de quantidade suficiente de extrato frạ cionado, foram utilizados os efluentes correspondentes a cinco corridas.

\subsection{Tratamento Tërmico}

Normalmente, o tratamento térmico do Extrato Total era realizado em autoclave vertical em frascos de $125 \mathrm{ml}$ contendo de 40 a $60 \mathrm{ml}$ de líquido, por tempos variados entre 30 e 60 minutos conforme a experiência.

As autoclavagens da Farinha de Soja Desengordurada (FSD) ou do Resíduo (R) foram feitas após adição de ãgua na proporção de $35: 10\left(\mathrm{H}_{2} \mathrm{O}: \mathrm{FSD} / \mathrm{R}\right)$.

No caso do ensaio agudo da experiência citada no 
item 7.1 .3 e primeiro ensaio semicrônico, a autoclavagem foi feita em erlenmeyers de 1,51 durante um periodo de 40 mirutos a 1 atmosfera de pressão e no segundo ensaio semicrônico em latas de $1,5 \mathrm{Kg}$ seguindo ciclo de temperatura, apresen.. tado na Figura 2.

Essas modificações foram introduzidas devido à neces sidade de manipulação de grandes quantidades de material.

- esquema para o fracionamento da Farinha de Soja Des sengordurada após autoclavação prévia (FSDA), seguiu o esqué matizado para a farinha não autoclavada (item 6.1.1) (Figura. 1).

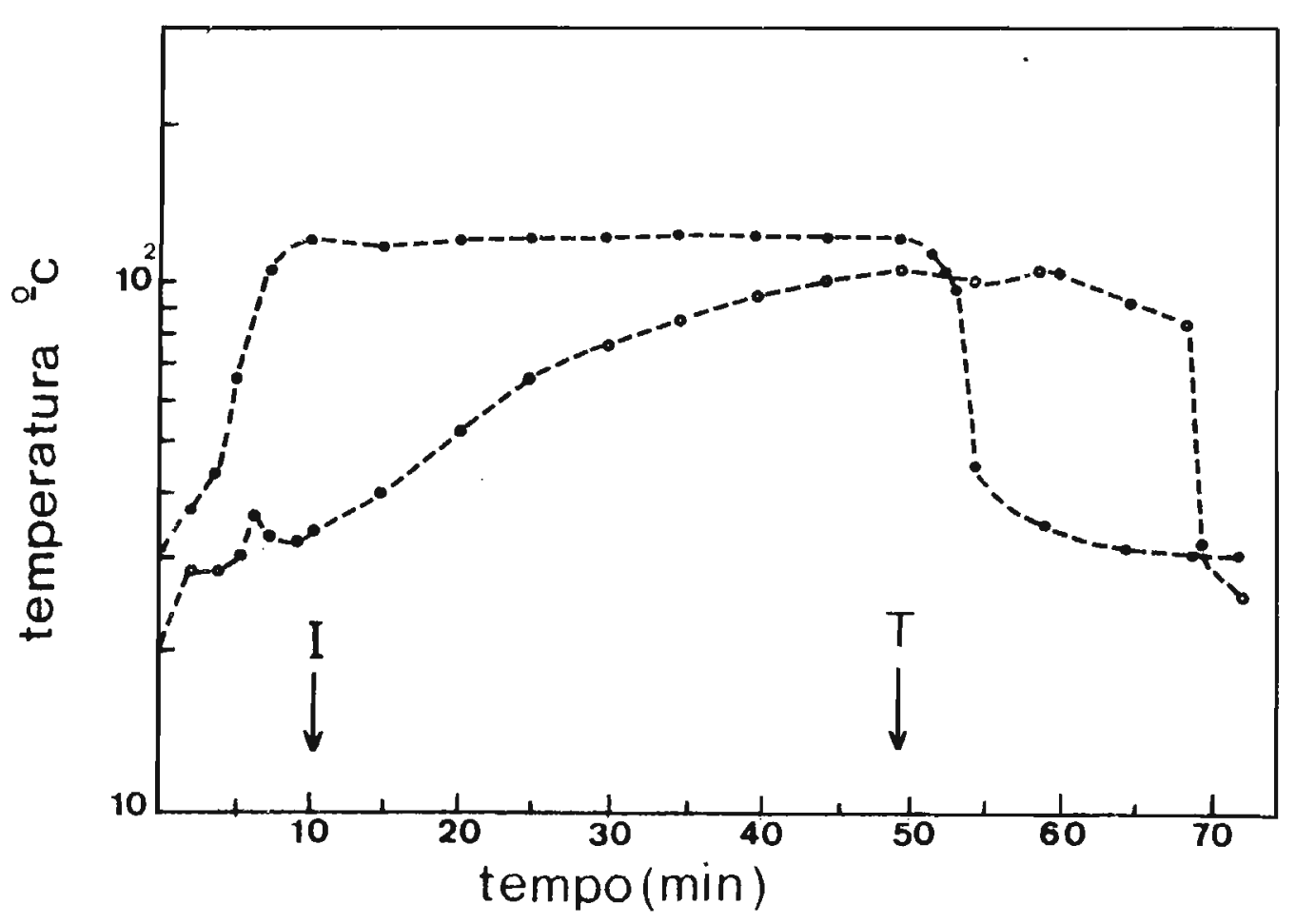

FIGURA 2: Variação da temperatura durante a autoclavagem da Farinha de Soja Desengordurada (FSD) em latas de $1 / 2 \mathrm{Kg}$. FSD $(\infty-\infty)$, autoclave $(--\infty), I=$ inicio e $T=$ término da autoclavagem. 


\subsection{Ensaios das Frações Obtidas}

\subsubsection{Ensaios agudos}

Nos valemos da técnica utilizada por KONIJN(19) modi ficada segundo o esquerna: $2 \mathrm{ml}$ da fração em estudo (Figura 1) correspondentes a ingestão de $4 \mathrm{~g}$ de Farinha de Soja Desengordurada foram administradas através de sonda gástrica a grupos de ratos mantidos em jejum por doze horas e alojados em gaiolas individuais. Os ratos controle recebiam, da mesma forma $2 \mathrm{ml}$ de solução fisiológica. Decorrida uma hora, injetava-se por via intraperitonial cerca de $5 \mu \mathrm{Ci}{ }^{13 I_{I} / 100 \mathrm{~g}}$ de peso de rato, num volume de $1 \mathrm{ml}$. Após a administração do radioiodo os animais eram alimentados com ração normal do biotërio.

Decorridas 24 horas (ou após tempos variáveis em certas experiências), os animais foram sacrificados por inalação de éter, as tireóides com a traquéía removidas, lavadas com solução fisiolögica e sua radioatividade medida.

O efeito do "fator" em estudo foi avaliado calculando-se a porcentagem de captação/100 g de peso do animal.

\subsubsection{Ensaios semicrônicos}

Nesse caso, as frações em estudo (Tabela I) foram adicionadas às rações experimentais. 
Findo o período experimental de 16 dias no primeiro en saio e 29 dias no segundo, os animais recebiam, por via intra peritoneal, $1 \mathrm{mI}$ de solução de ${ }^{131^{1}} \mathrm{I}$ com $10 \mu \mathrm{Ci} / \mathrm{ml}$ por 100 $g$ de rato. Apôs 24 horas os animais eram sacrificados com éter etílico e as suas tireóides removidas com cuidado para evitar que se rompessem. As glândulas eram lavadas com solução fisiológica, pesadas imediatamente e a radioatividade medida em cintilador.

o efeito da fração em estudo foi avaliado por diferen tes parâmetros como: peso da glândula, \& da captação, nível de hormônios tireoideanos e séricos e índices de crescimento.

6.4 Determinação da Porcentagem de Captação

A porcentagem de captação foi calculada dividindo-se - nümero de contagens obtidas com a tireōide por aquelas obtidas contando-se, nas mesmas condições, $1 \mathrm{ml}$ de uma dilui ção conveniente da solução padrão injetada nos animais e multiplicando-se a razão por 100 .

Em todos os casos as contagens foram superiones a 10.000 para marter-se 0 erro estatístico de contagem inferior a $1 \%$. 
6.5 Doseamento dos Hormônios da Tireóide

\subsubsection{Preparo do hidrolisado}

Logo após a medida da radioatividade cada tireöide foi macerada em homogenizador mecânico com l ml de tampão TRIS- $\mathrm{HCl} 0,1 \mathrm{M}, \mathrm{pH} 8,6$ contendo: $0,1 \%$ de tiouracilo, $0,9 \%$ de $\mathrm{NaCl}$ e $0,1 \%$ de pronase; após a homogenização acrescen tavam-se mais $2 \mathrm{ml}$ de pronase a $0,1 \%$ dissolvida no mesmo tampão sendo os macerados deixados em estufa a $37^{\circ} \mathrm{C}$ por vinte e quatro horas, para a digestão enzimätica ${ }^{(20)}$. Os hidrolisados de cada glândula eram centrifugados a 6.000 r.p.m. durante vinte minutos e os sobrenadantes utilizados natro matografia.

6.5.2 Separação dos hormônios

A separação dos hormônios foi efetuada por cromatografia descendente em papel Whatman $3 M^{(16)}$, tendo os cromatogramas de cada hidrolisado sido desenvolvidosem dois sistemas de solventes distintos. 


\section{Sistema 1: para Iodotirosinas}

n-butanol:äcido acético:ägua $(4: 1: 5)$

Os solventes foram colocados em funil de separação na proporção citada acima, e após agitação deixou-se a mistura em repouso por quatro horas a $4^{\circ} \mathrm{C}$. A fase superior foi utilizada no desenvolvimento dos cromatogramas a inferior para saturação prévia do sistema.

\section{Sistema 2: para Iodotironinas}

$$
\mathrm{NH}_{4} \mathrm{OH} 2 \mathrm{~N}: n \text {-butanol }(1: 1)
$$

Os solventes foram colocados em funil de separação, e após agitação deixou-se a mistura em repouso por quatro ho ras a $4^{\circ} \mathrm{C}$. A fase superior foi utilizada no desenvolvimento dos cromatogramas e a inferior para saturação prévia do siste ma.

Para as corridas, $500 \mu l$ do hidrolisado de cada glân dula foram misturadas com $100 \mu \mathrm{l}$ de mistura de padrões $(2 \mathrm{mg}$ de NaI + $2 \mathrm{mg}$ de MIT $+2 \mathrm{mg}$ de DIT $+8 \mathrm{mg} \mathrm{T}{ }_{3}+8 \mathrm{mg} \mathrm{T} \mathrm{T}_{4}$ dissolvidos em $4 \mathrm{mI}$ de $\mathrm{NH}_{4} \mathrm{OH} 2 \mathrm{~N}$ )"

*(MIT) monoiodotirosina, (DIT) iodotirosina, ( ${ }_{3}$ ) irio dotironina, $\left(\mathrm{T}_{4}\right)$ Tiroxina. 
200 ul dessa mistura foram então aplicados ao papel em estrias de $1,5 \mathrm{~cm}$. Apös as marchas estarem secas, os cromatogramas foram levados para saturar nas cubas que conti nham a fase aquosa dos respectivos solventes e após um período de cinco horas a fase butanöisca foi colocada em contacto com os cromatogramas. o tempo de desenvolvimento foi de quin ze horas.

Finda a corrida, os cromatogramas foram secados e re velados quimicamente. Para os compostos com grupamentc fenólico utilizou-se o reativo de PAULY ${ }^{(5)}$ e para localização do iodeto sódio, o cloreto de palädio a $1 \%$ em solução aquosa acidificada com $\mathrm{HCl}(\mathrm{pH}=3)$.

\section{5 .3 Contagens}

Após revelação química os cromatogramas foram seca dos ao ar novamente, recortados em tiras de $1 \mathrm{~cm}$. de largu ra (na direção origem + front) e a radioatividade de cada tira determinada em detector de cintilações. As contagens correspondentes a um determinado hormônio, identificado quimicamente, foram agrupadas para se calcular sua porcentagem em relação à soma total das contagens do cromatograma.

Nas Figuras 3 e 4 encontram-se representados duas das corridas realizadas, a título de ilustração e avaliação da tëcnica empregada. 


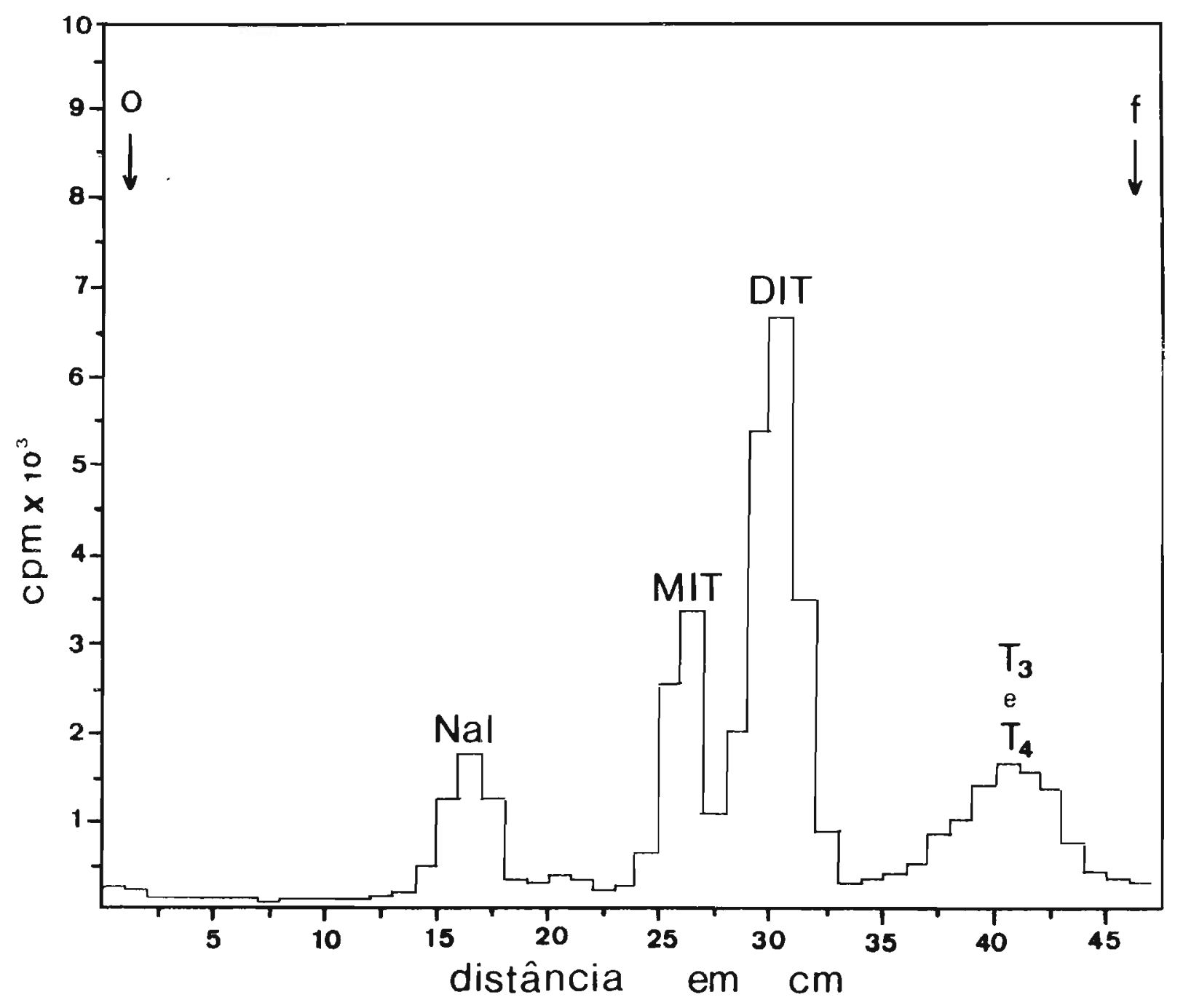

FIGURA 3: Perfil cromatográfico das contagens de hidrolisado de tireólde no sistema solvente 1 . 0 = origem; $F$ = frontes c.p.m. = contagens por minuto. 


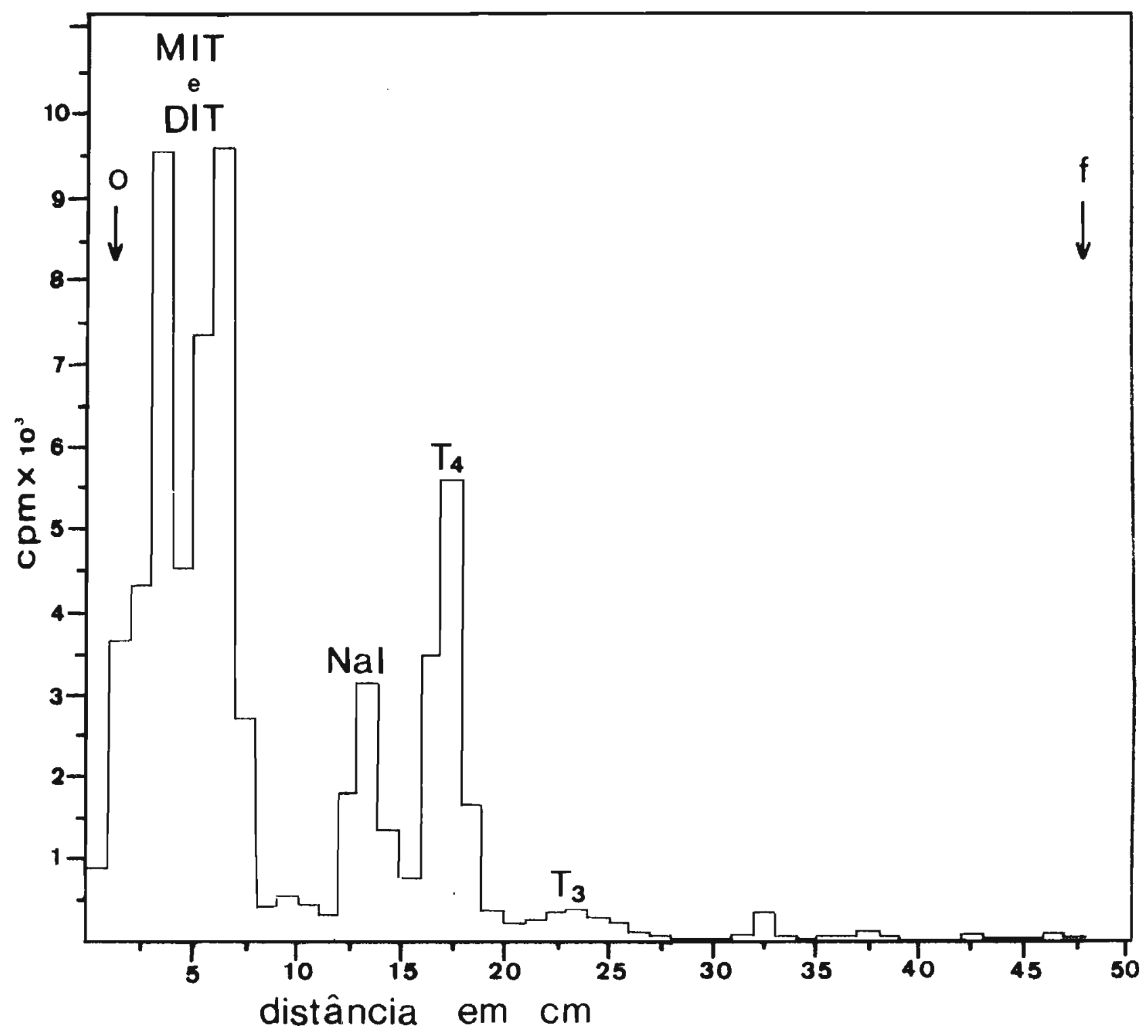

FIGURA 4: Perfil cromatogräfico das contagens de hidrolisado de tireólde no sistema solvente $2.0=$ orlgem, $F=$ fronte, c.p.m. = contagens por minuto. 
6.6 Doseamento dos Hormônios Séricos

\subsubsection{Obtenção do soro}

Antes da remoção das tireöides os animais eram levemente anestesiados com éter etílico e através punção cardíaca retiravam-se $5 \mathrm{ml}$ de sangue. Para evitar hemölise e obter-se uma boa retração do coăgulo utilizaram-se, para cada animal, seringa e tubo de ensaio previamente siliconizados. Após coagulação, o soro era separado por centrifugação a 2.000 $r . p . m$. e congelaco a $-20^{\circ} \mathrm{C}$ para posterior análise dos homônios.

6.6.2 Medida indireta da função tireoidiana

Baseada no método de LEONARDS ${ }^{(22)}$; utilizamos para esse fim o sistema Trilute (Ames Yissum, Ltda, Israel). A quantidade de soro usada na medida, para cada animal, foi de $0,15 \mathrm{ml}$.

\subsubsection{Radioimunoensaio}

Para a dosagem do $\mathrm{T}_{3}$ empregamos 0 sistema $\mathrm{T}_{3}$ Dow-Le petit (Lepetit S.A) e para a dosagem do $T_{4} \circ$ sistema Quantimune $\mathrm{T}_{4}$ Ria (Bio-Rad Laboratories). 
6.7 Testes Preliminares para Identificação dos Compostos Presentes no Extrato Total e em suas Frações

6.7.1 Espectros de absorção

Os espectros foram obtidos em solução aquosa ou eta nólica ( $90 \%)$ na diluição de $1 / 600$.

6.7.2 Glicides solüveis em ägua

Foram detectados através de reaçōes em tudo de ensaio com resorcinol (reação de Seliwanoff) ${ }^{(52)}$, benzidina + ăcido tricloro acético ${ }^{(5)}$ e reação de Molish-Udransky ${ }^{(52)}$.

6.7.3 Grupo a-amínico Iivre

Avaliados atravēs das reações em tubo de ensaio com reagente de ninhidrina segundo método de SPIES ${ }^{(47)}$.

6.7.4 Flavonüides

Detectados através das reações com $\mathrm{FeCl}_{3}$ a $58 \mathrm{Na}_{2} \mathrm{CO}_{3}$ a 10\%, segundo SEIKEL ${ }^{(43)}$. 
Foram efetuados tambẻm reações em forma de "spottest" sendo os reveladores empregados UV, vapores de $\mathrm{NH}_{3} \mathrm{e}$ vapores de $\mathrm{NH}_{3}+\mathrm{UV}^{(43)}$. Nos valemos tambëm da cromatografia em papel Whatman $3 \mathrm{MM}^{(43)}$ com n-butanol: äcido acético: $\mathrm{H}_{2} \mathrm{O}(4: 1: 5)$, preparado conforme item 6.5.2.

Os reveladores empregados foram UV, vapores de $\mathrm{NH}_{3}$, vapores de $\mathrm{NH}_{3}+\mathrm{UV}, \mathrm{Na}_{2} \mathrm{CO}_{3} 10 \%$ e $\mathrm{FeCl}_{3} 5 \%$.

\subsection{Métodos Estatísticos}

Foram realizados 3 tipos de anälise estatística:

a) Teste "t" de Student para comparação entre duas mêdias $(7)$

* b) Análise de Variância. Nos casos em que pela análise se rejeitou a hipótese de igualdade das médias dos gru pos, três soluções foram tomadas; em certos casos fez-se a comparação de cada grupo com o controle (Técnica de DUNNET) $)^{(7)}$, em outros usou-se a técnica de anälise de conglomerados para agrupar os tratamentos semelhantes (Táonica de SCOTT e KNOTT) ${ }^{(41)}$ e no caso de doseamen

\footnotetext{
"Realizada pelos Profs. Clovis Araujo Peres, Wilton Oliveira Bussab e Dalton Francisco de Andrade, do Instituto de Matemá tica e Estatística da USP.
} 
to dos hormônios tireoidianos no segundo ensaio semicrô nico, nos valemos da técnica de FISHER ${ }^{(7)}$.

* c) Anälise de Covariância. Foi utilizada nas variảveis que dependiam de algum modo do peso inicial, para eliminar-se o efeito do peso inicial do rato. Quando a hipótese de igualdade entre as médias ajustadas foi rejeitada, passou-se a técnica de agrupamento das médias (Técnica de SCOTT e KNOTT $(41)$.

O nível mínimo de significância considerado foi de $5 \%$ ou 18 conforme o caso. 
7 RESULTADOS E DISCUSSAO

7.1 Ensaios Agudos Realizados com os Extratos de Farinha de Soja Desengordurada (FSD)

Os efeitos agudos foram obtidos, como descrito em 6.3.1, administrando-se extratos de soja a ratos, e avaliando-se a sua ação por medida da captação de ${ }^{13 I_{I}}$ pela tireóide após prazos variâveis de 3 a 24 horas. Os extratos, tratados ou não termicamente, consistiam dos Extratos Totais (ET), frações razoavelmente purificadas (6.1) (Figura 1) jáa que boa parte das proteinas (contendo inclusive fitohemaglutinina e antitripsina) eram eliminadas por precipitação isoelétrica em $\mathrm{pH} 4.2$ e, numa segunda fase, pelo tratamento com acetona $(19)(24)(40)$.

7.1.1 Efeito do Extrato Total não autoclavado. Ação em 24 horas

Extratos Totais, não autoclavados, preparados a partir de Farinha de Soja Desengordurada Crua, administrados a ratos por sonda gástrica não causaram, após 24 horas de ação, qualquer variação significativa na porcentagem de captação de ${ }^{13 I_{I}}$ pela tireóide (Tabala III). 


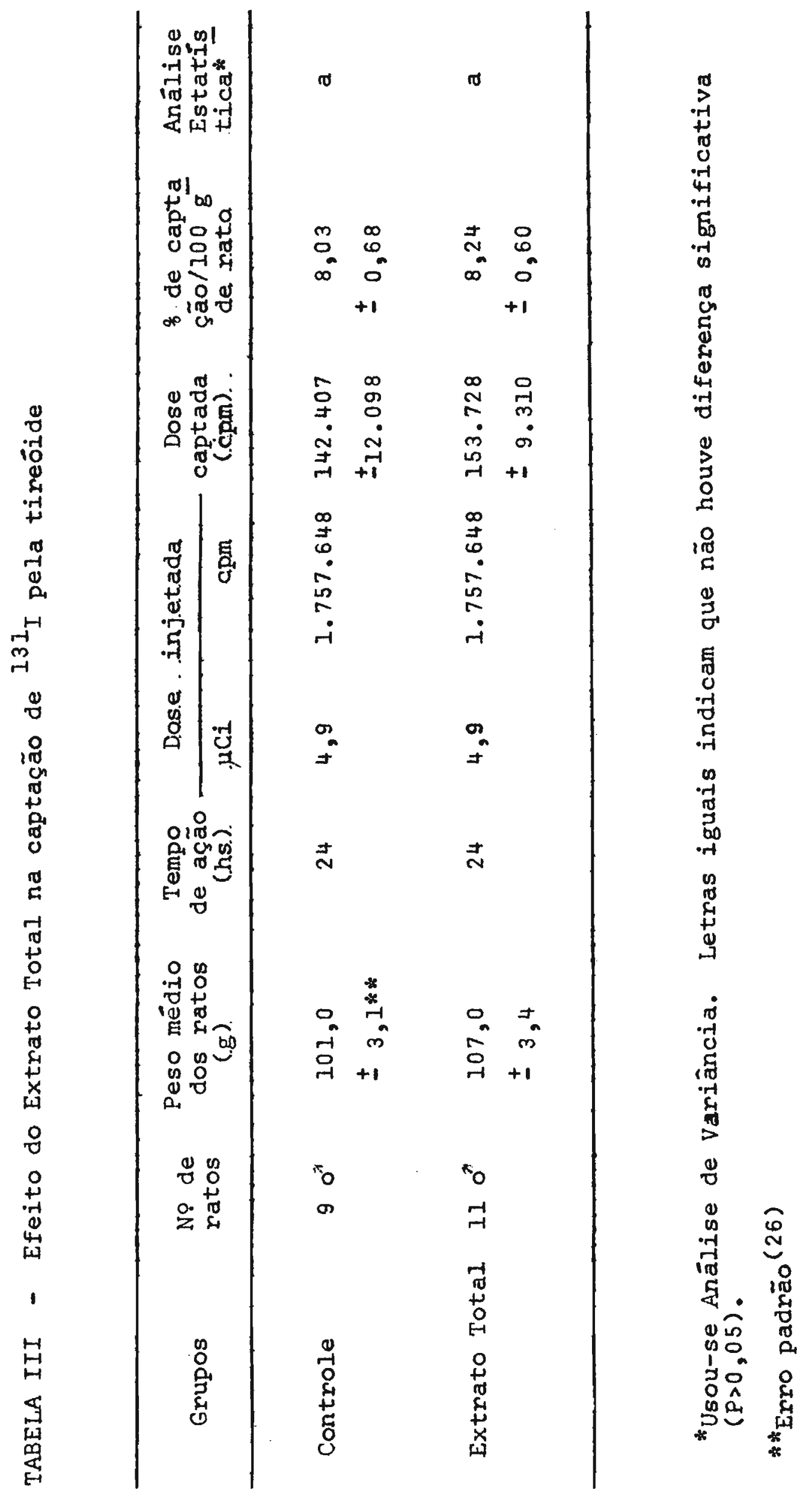


Ensaios preliminares realizados anteriormente com propiltiouracilo nos haviam indicado a eficiência da têcnica escolhida; testes prévios realizados com um produto comercial de soja haviam também indicado uma ação mensurãvel, fatos esses que em vista dos resultados negativos da Tabela III, nos levaram à repetição da experiência.

Na Tabela IV encontram-se os resultados dessa primei ra repetição, bem como de outras, realizadas posteriomente, num espaço de 20 meses a partir de 18 ensaio. Como se vê pela tabela, apenas en um caso, entre as 3 repetiçöes, houve redução significativa da captação $(P \leqslant 0,05)$, o que representą va uma confirmação muito fraca dos resultados obtidos na nossa experiência piloto.

Os resultados pareciam apenas refletir a confusão existentes na literatura sobre a existência - não existência de substâncias ativas $(12)(20)(45)(46)$. Faltava ainda explicar a ação (exceção) obtida na terceira repetição (concluimos mais tarde que a exceção obtida poderia ser explicada por um excesso de aquecimento durante a preparação dos extratos usados nessa experiência).

7.1.2 Efeito do Extrato Total näo Autoclavado. Ação de 3 a 24 horas

Pensando que uma possível metabolização pudesse eliminar a ação do composto ativo, no prazo empregado inicial mente, de 24 horas, realizamos experiências procurando ava - 


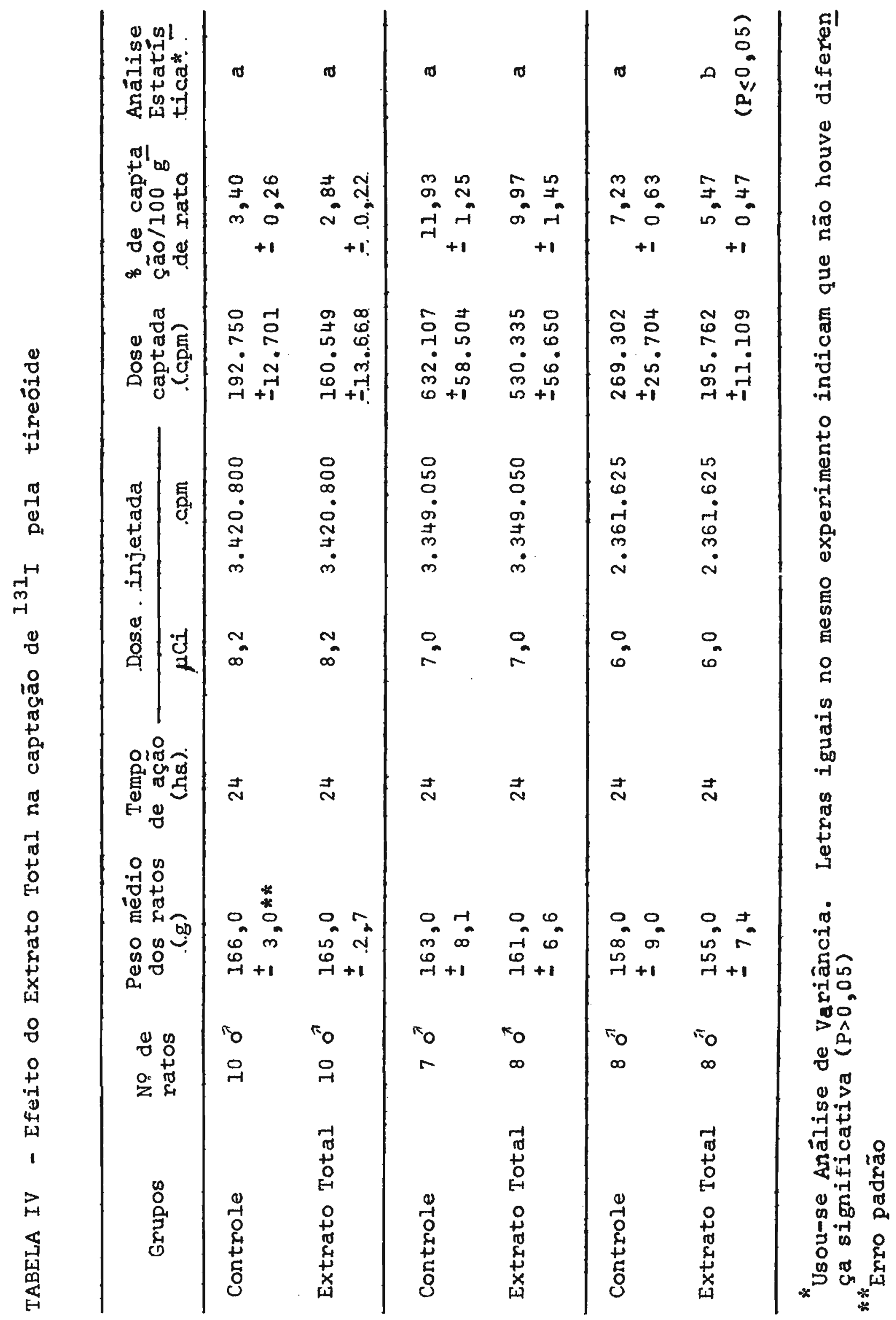


liar a ação após tempos menores decorridas entre a ingestão dos extratos e a medida da captação.

Os resultados, de várias repetições encontram-se na Tabela $\mathrm{V}$ e mostram que existe de fato um fator ativo ( $F$ ) que consegue diminuir a captação de ${ }^{13}$ I pela tireóide e cuja ação se inicia após 3 horas de administração mas que desaparece de corridas 24 horas.

A observação feita explica, em parte, a discrepância de certos dados da literatura, que poderiam ser devidos ao tipo de técnica usada para a detecção da ação tóxica.

Para os resultados obtidos, vārias explicações nos ocorreram como:

a) O fator ativo (F) seria, como pensado, rapidamente eliminado ou inativado no organismo (detoxificado, hidrolizado, com perda de ação) o que ocorreria entre 6 e 24 horas apös a administração.

b) (F) seria composto de duas substâncias, daquela ativa (A) e uma inibidora ou antagonista (I), cujas velocidades de: absorção ou metabolização ou de excreção, fossem diferentes. Assim, por exemplo, se a absorção de (I) fosse mais lenta, ou se (I) existisse na forma de um precursor que levasse algumas horas para tor nar-se ativo, a ação seria aquela obtida nos nossos resultados.

c) O fator (F) poderia, também, existir na forma de um precursor (ou precursores) inativo, sendo que apenas 


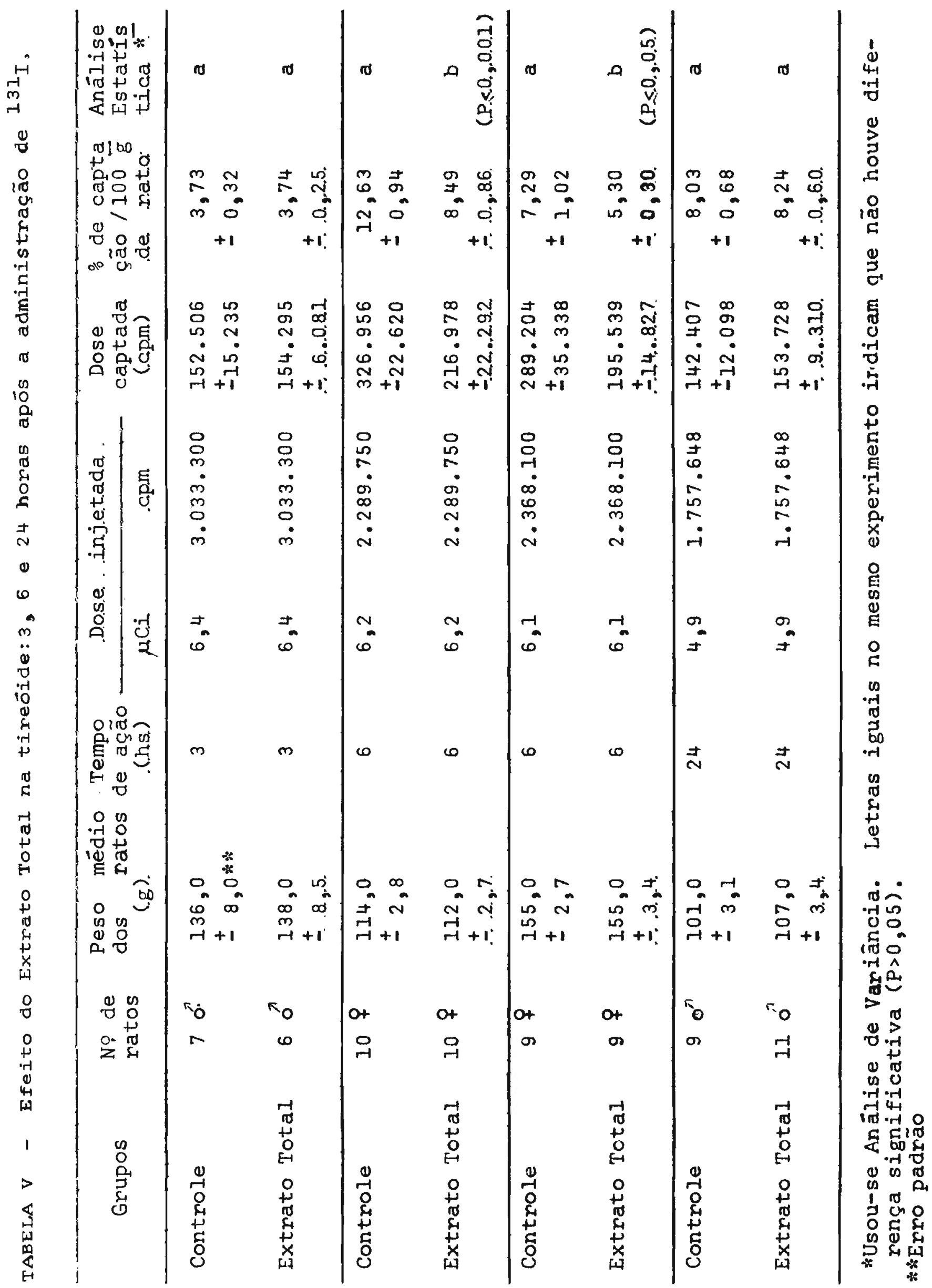


uma pequena fração estaria na forma livre; e cuja quan tidade só seria suficiente para agir num período de tempo curto ( 6 horas). Essa quantidade poderia ser formada na preparação do extrato.

7.1.3 Efeito da Autoclavagem sobre a ação do Extrato Total. Ação em 24 horas

A possibilidade inferida, da existência de mais de uma substância ou de um precursor inativo, nos levou a tentar discriminar a ação das mesmas e, como poderiam ter labilidades tẻrmicas diferentes, realizamos experiências exploratórias, comparando a açāo de Extratos Totais Autoclavados com a do Extrato Total Cru.

Esses resultados encontram-se na Tabela VI e mostram (em duas repetições) que a autoclavagem do extrato total entre 30-60 min., faz com que o mesmo se torne operante na depressão da captação confirmando de um lado, a existência, ries se extrato, de uma substāncia ativa e, por outro negando a hipótese "a", levantada anteriormente.

Outro aspecto importante é que essa substância è resistente ao tratamento térmico de $121^{\circ} \mathrm{C}$ por $60 \mathrm{~min}$, mesmo em solução; possivelmente ela deveria resistir a processamento industrial, o que foi confirmado (ver adiante).

Havia, ainda, porém, a possibilidade da substância ativa ter sido "produzida" como resultado de uma reação ocorrida durante a autoclavagem do Extrato Total e desse modo se- 


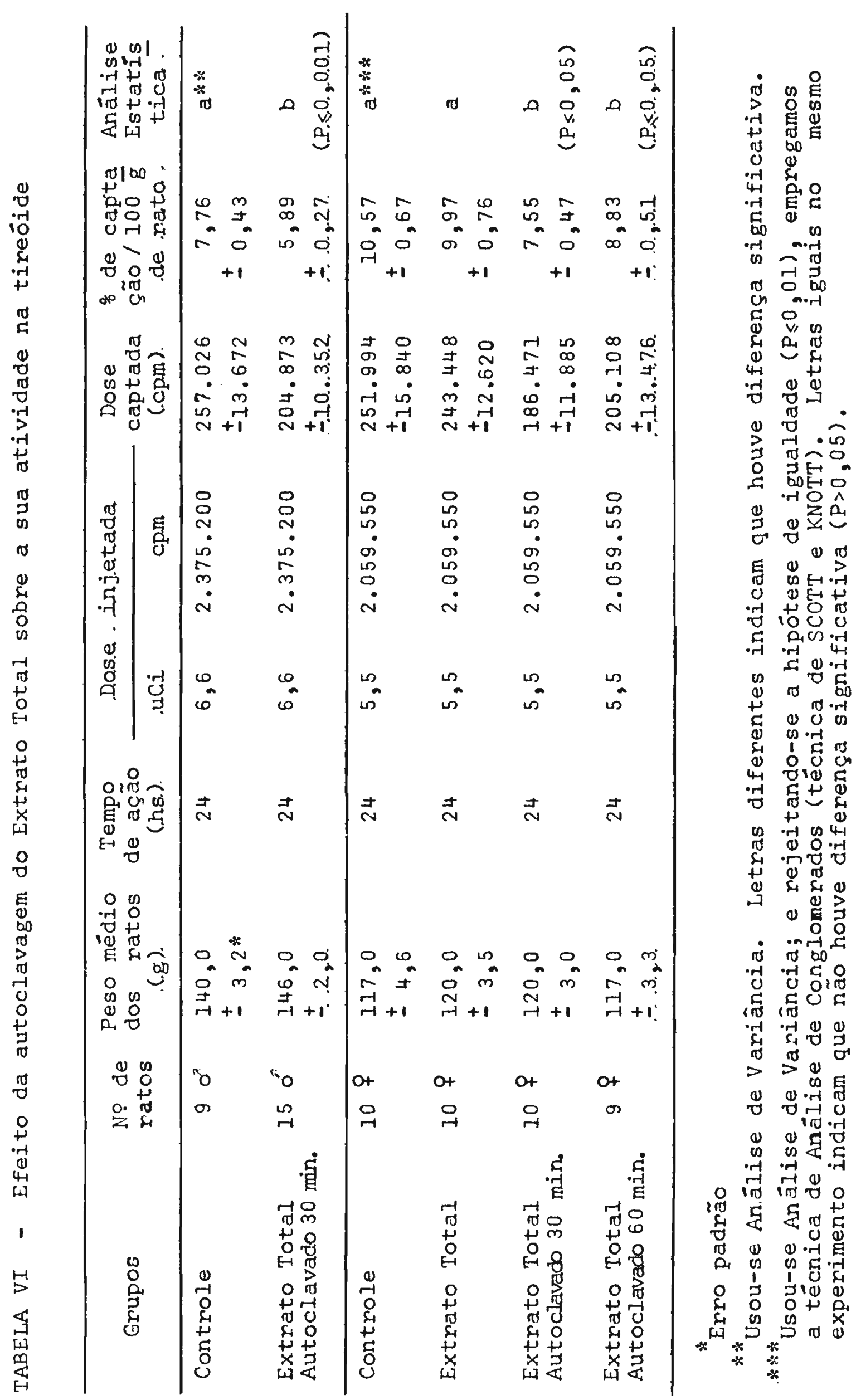


ria apenas um "artefato", mas não uma substância existente na soja.

Diante disso realizamos testes onde autoclavamos a Farinha de Soja Desengordurada, em suspensão aquosa para depois separar o Extrato Total e testa-1o.

Os resultados da Tabela VII mostram que a ação foi a mes ma que ocorreu no caso do aquecimento do extrato, indicando tratar-se de substância preexistente na soja e não formada ar tificialmente na autoclavagem do Extrato Total. Pelo mesmo raciocinio conclue-se que, devido às diferenças observadas an tes e depois da autoclavagem, a mesma substância também não poderia ser formada durante a preparação do extrato, fase em que as condições utilizadas são menos severas.

7.1.4 Efeito da autoclavagem sobre a ação do Extrato Total. Ação em 6 horas

Na tentativa de discriminar mais entre as explica ções alternativas apresentadas, realizamos essas experiēncias cujos resultados encontram-se na Tabela VIII. Elas confirmam a ação após 24 horas, mesmo apōs autoclavagem e a ação, também nas 6 horas, da mesma forma como acontece quando não há aquecimento.

A Figura 5 ilustra melhor do que as Tabelas a evolução da ação observada em função do tempo de ação e da autoclavagem .

Como o tratamento térmico faz com que a ação depres- 


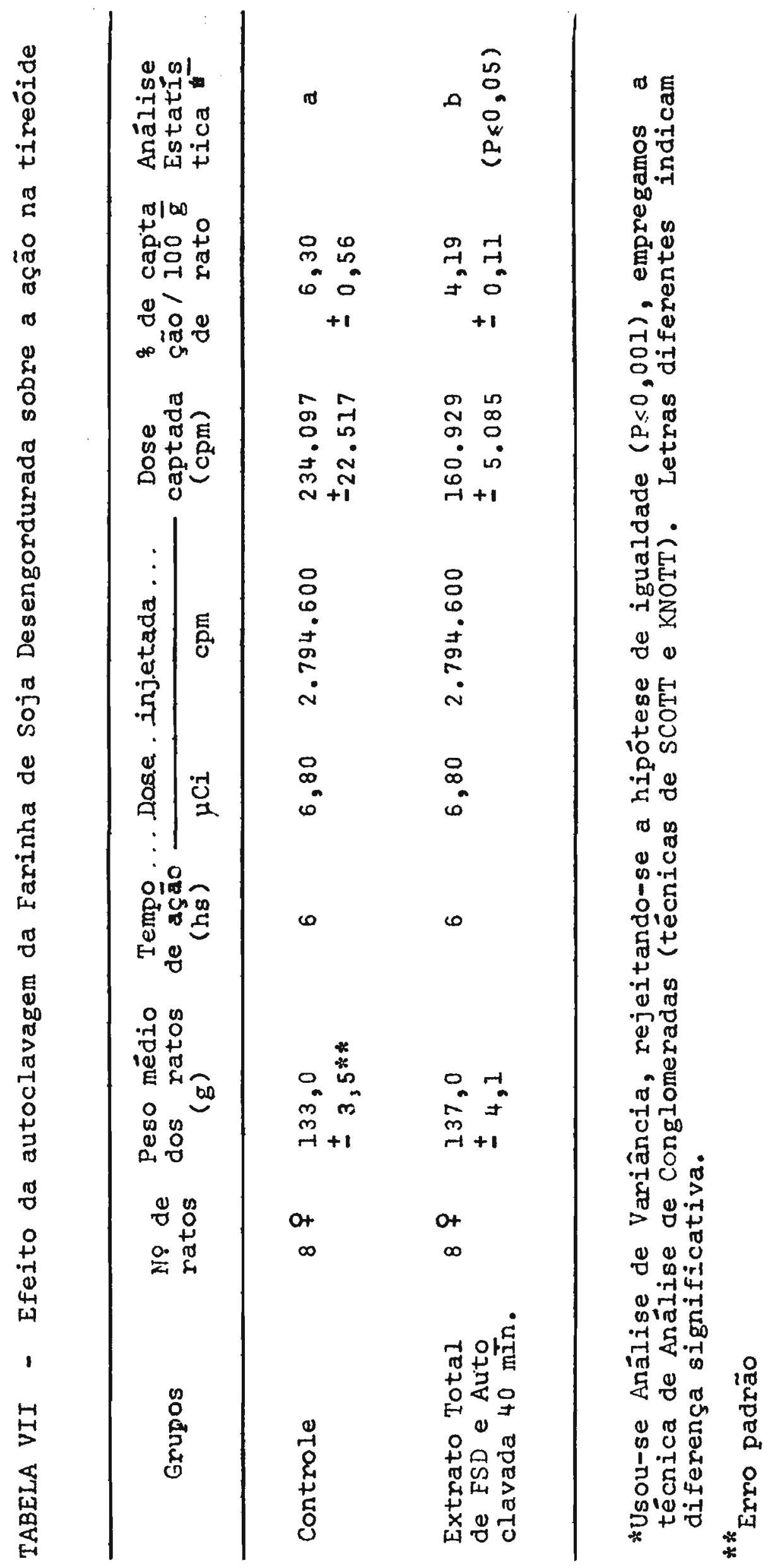




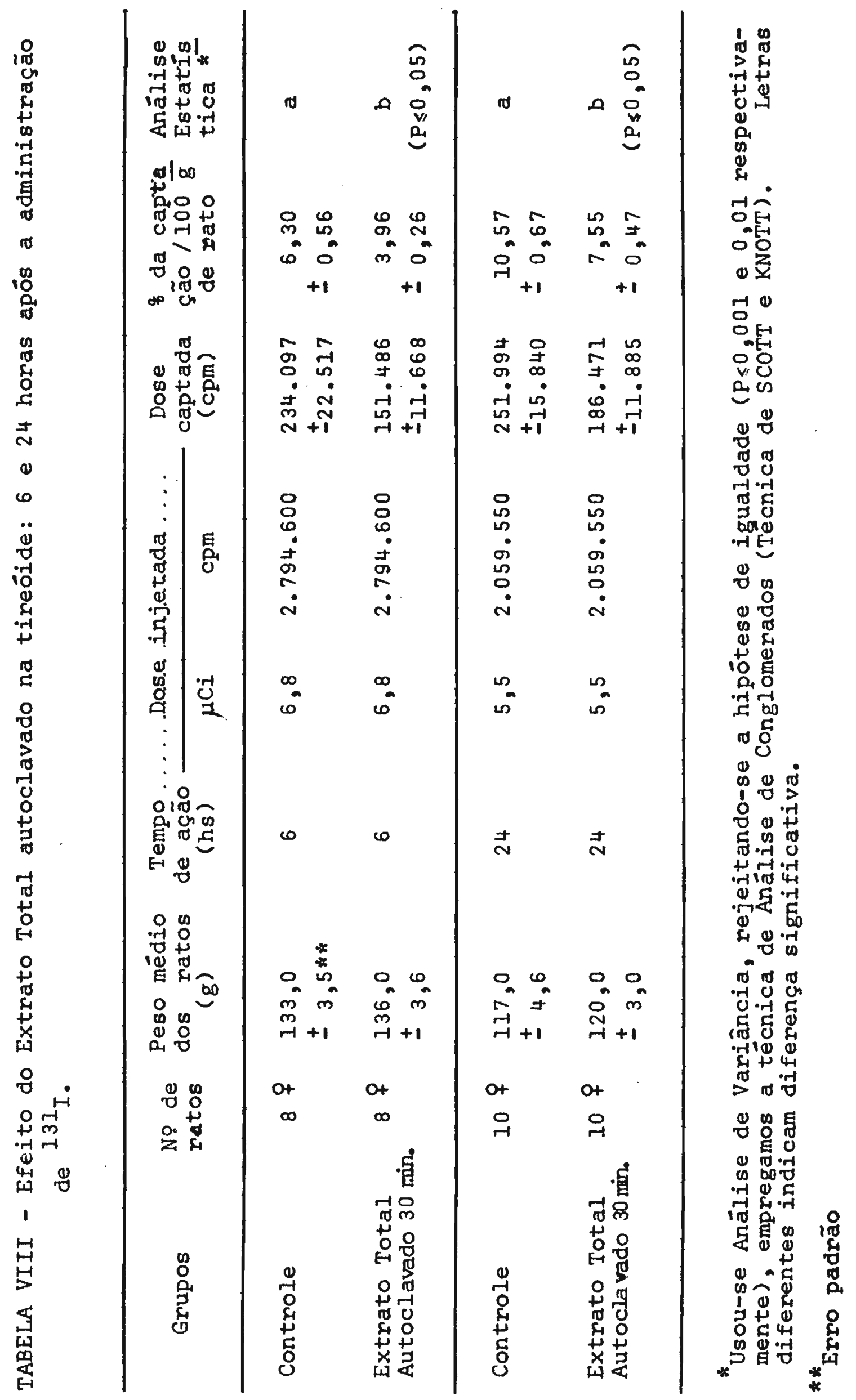




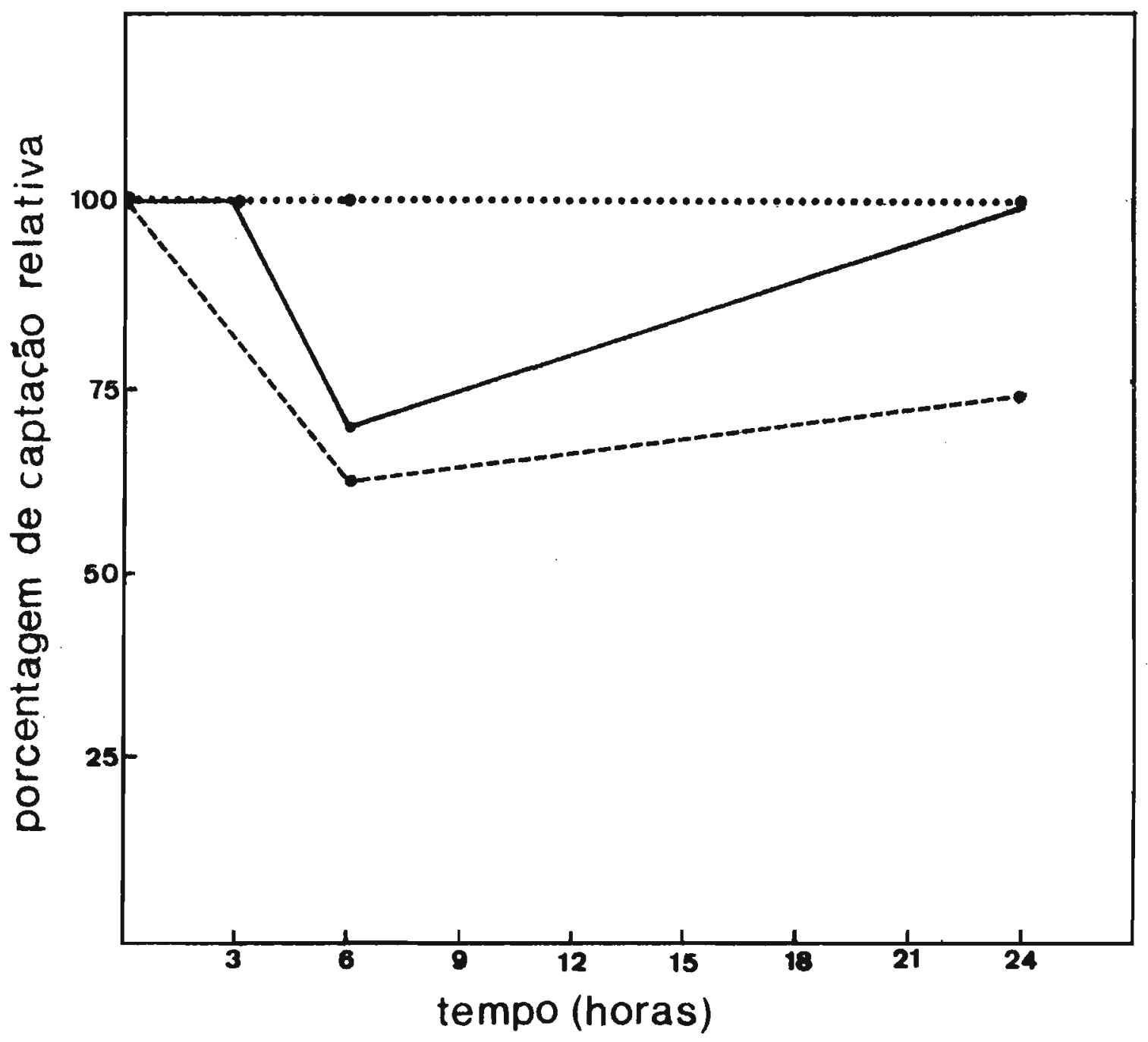

FIGURA 5: Efelto da autoclayagem do Extrato Total na \& de cap tação/100 g de rato em função do tempo de ação. (........) contro le: (-) Extrato Total, (--.) Extrato Total Autoclavado. A \& de captação/100g de rato fol considerada em relação ao grupo controle, cujo valor era 1 gual a 100. 
sora permaneça após 6 horas é possivel que ele tenha destruido uma segunda substância (I) que como suposto, agiria de for ma oposta à da substância ativa (A) ou seja, aumentando a cap tação de ${ }^{13 I}$ I pela tireōide (hipōtese b).

No caso do fator existir na forma de um precursor (hi pótese c) o aquecimento foderia levar à formação da substân cia ativa que alcançaria uma concentração suficiente para agir nas 6 horas como nas 24 horas. Não hă elementos finais nesta altura para decidir, mas a altemativa $\subseteq$ parece próxima da rea lidade.

7.2 Ensaios Agudos dos Produtos Obtidos por Fracionamento do Extrato Total

Na tentativa de isolar as substâncias envolvidas para posterior identificação e de testar as hipóteses levanta das, procuramos obter frações ativas (que aumentassem ou diminuissem a captação do ${ }^{131}$ I) o que foi feito por tratamento com etanol ou por separação em coluna de peneira molecular.

Dentre as substâncias candidatas a serem, segundo as hipöteses levantadas, fatores ativos ou fatores inibidores ou ainda, precursores de ambos, os flavonóides pareciam adequados.

A substância ativa (A) poderia, por exemplo, ser um flavonöide, existente como precursor na forma de glicosídeo inativo, que se hidrolisaria por aquecimento, passando a agir. 
A ação nas 6 horas seria explicada como dissemos pela pequena quantidade existente na forma livre que metaboliza da não conseguiria agir após 24 horas.

Essa idéia encontra apoio no fato jā verificado de que os flavonóides conseguem tanto aumentar $(28)(34)$ como dimi nuir (18) o metabolismo basal em animais, bem como aumentar ${ }^{(35)}$ (42) ou diminuir ${ }^{(42)}$ a captação de ${ }^{131}$ I pela tireóide.

0 mecanismo envolvido parece estar relacionado com uma ação ao nível das peroxidases tireoidianas ${ }^{(18)(29)}$ ou ainda ao nível de competição entre os grupos fenólicos de flavonóides e os da tirosina, na fase da organização do iodo(18)(29).

A análise dos vários resultados apresentados na literatura sobre a soja, não nos auxiliaram muito; alguns eutores (44) observaram, por exemplo, que um fator bociogênico da soja era solüvel em ëter etilico e acetona, pois com o tratamento por esse solvente a soja perdia essa ação. Já, segundo outros, o tratamento com êter etílico, acetona, clorofórmio as etanol não eram capazes de remover a ação bociogênica (12)(53).

Um ünico trabalho recente evidencia que, em extratos de soja, se consegue precipitar o fator ativo com acetona a $90 \%$, éter etílico a $90 \%$ ou etanol a $90 \%(19)$.

Realizamos assim uma série de experiências preliminares para verificar a presença de flavonóides no nosso extrato.

Inicialmente verificamos que o espectro de absorção do Extrato Total, entre 360 a $170 \mathrm{~nm}$ mostrava dois pontos de máxima: um por volta de $200 \mathrm{~nm}$ que poderia ser devido a peptídeos e outro em tomo de $260 \mathrm{~nm}$ que, pelo histórico 
do extrato seria devido principalmente a flavonóides.

A cromatografia ascendente do Extrato Total, autoclavado ou cru, em papel whatman 3 MM, evidenciou um grande núme ro de manchas sobrepostas que davam reação positiva em UV, vapores de amônia, vapores de amônia $+\mathrm{UV}, \mathrm{Na}_{2} \mathrm{CO}_{3}$ a $10 \%$ e $\mathrm{FeCl}_{3} 5 \%$, indicando a presença de värios flavonóides diferen tes e tambể, de outros compostos fenólicos.

Por precipitação do Extrato Total com etanol a $90 \%$ obtivemos um precipitado, com absorção mäxima em $194 \mathrm{~nm}$ e um sobrenadante que mantinha os dois picos em $197 \mathrm{~nm}$ e $259 \mathrm{~nm}$ (Figura 6).

o desaparecimento do pico em $259 \mathrm{~nm}$ foi tomado como in dicativo de eliminação de boa parte dos flavonóides, fato que foi confimado pela realização de reações específicas como descrito acima.

As frações separadas foram testadas em animais na esperança de termos conseguido separação entre (A) e (I), mas não tivemos sucesso (Tabela IX).

E importante comentar, porém, que para a precipita ção com etanol partimos do extrato cru.

Os resultados obtidos por KONIJN et al. (19) que conseguiram precipitar um fator com etanol a $90 \%$, talvez se devesse ao fato dos mesmos trabalhar com soja que já apresentava o composto ativo livre.

Na tentativa de purificarmos mais o Extrato Total, a caminho de um possivel isolamento e identificação, o mesmo foi, com sucesso, fracionado em coluna de Sephadex G-25 médio ou fino por eluição com acetato de amônio $0,02 \mathrm{M}$ (item $6.1 .3)$. 


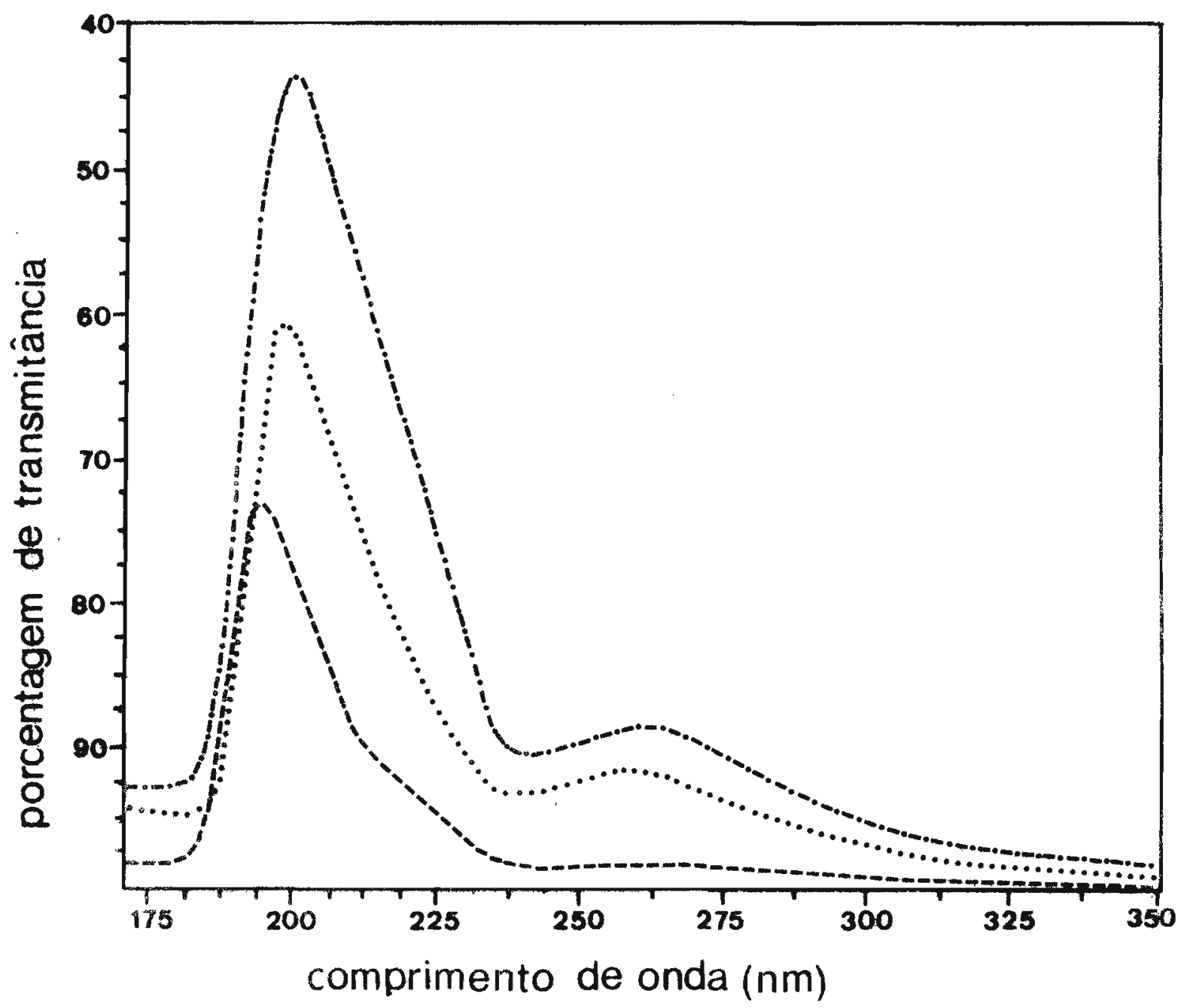

FIGURA 6: Espectro de absorção na falxa de ultravioleta (-..--) Extrato Total, (......) Sobrenadante Et-OH 908 ; (-.--) Precipitado $E t \leftarrow O H$ 908, em solução aquosa. Diluição final $1 / 600$. 


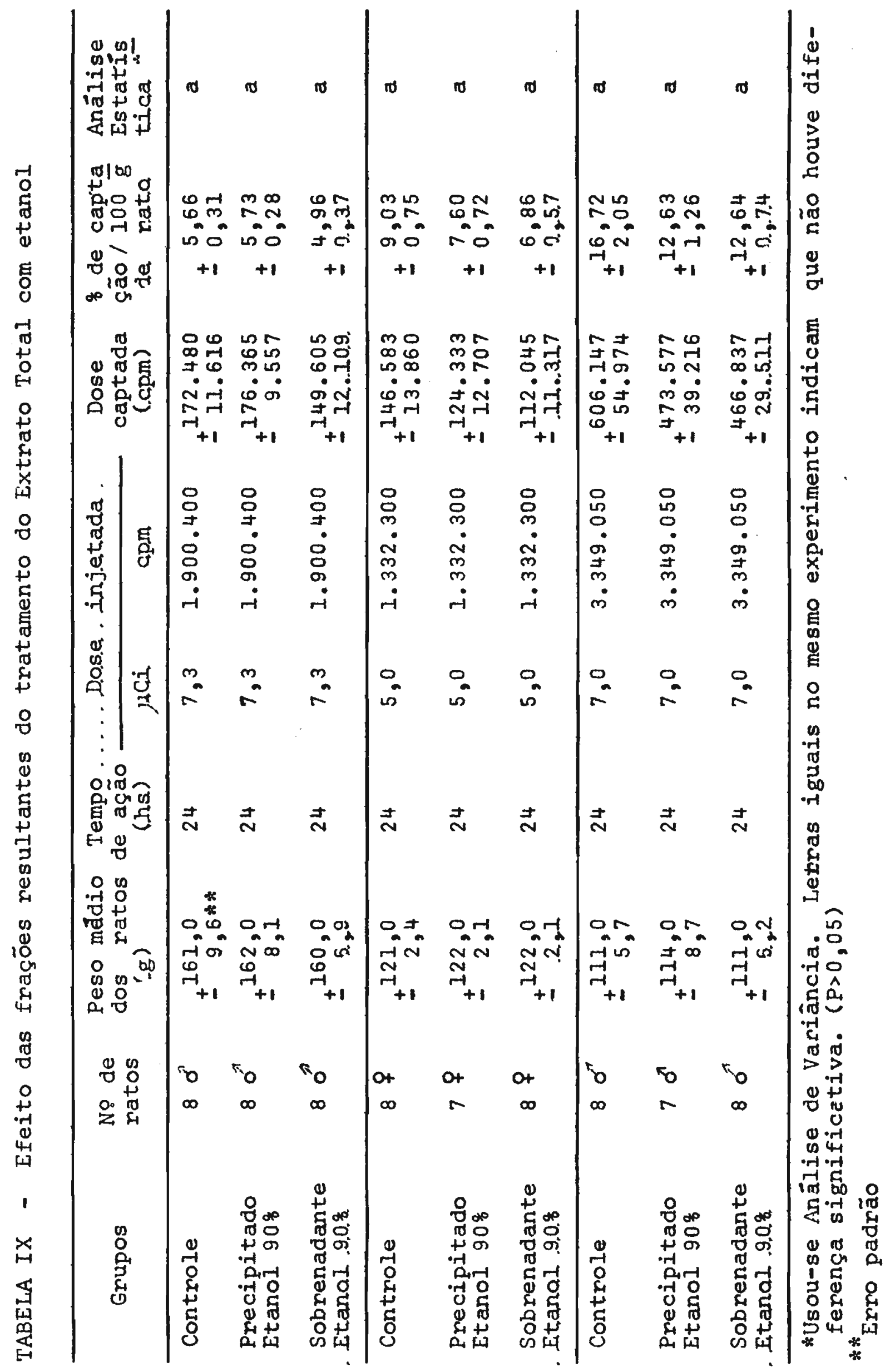


Obtivemos 8 frações, segundo o perfil cromatográfico mostrado na Figura 7, que apōs concentração foram testados (item 6.3.I) verificando-se que apenas uma delas, a Fração II era ativa; os resultados de duas repetições encontram-se nas Tabelas $\mathrm{X}$ e XI.

Pensamos, também, que fosse possível encontrar alguma fração que agisse de forma oposta ao fator, aumentando portanto a captação de ${ }^{131} \mathrm{I}$ o que nos daria mais indicação na direção das hipóteses levantadas anteriormente (da existência de substância antagônica).

$\mathrm{Na}$ primeira experiência, as Frações III e VII mostraram essa tendência que não se mostra, porëm, estatisticamente significativa. $\mathrm{Na}$ segunda repetição, novamente os resultados foram negativos. Devemos comentar aqui a dificuldade de in terpretação dos resultados que encontramos pois o Extrato Total, apesar de não ter sido autoclavado, mostrou-se ativo; re tomaremos adiante a discussão desse aspecto.

De qualquer forma, o fracionamento em Sephadex resultou numa purificação, mesmo que parcial, do extrato original, Iiberando o fator de uma série de componentes que foram retardados na coluna. Esse retardamento, foi maior do que era de se esperar, indicando algum tipo de interação com a dextrana, possivelmente, devido a presença de grupamentos aromáticos nas ültimas frações. 


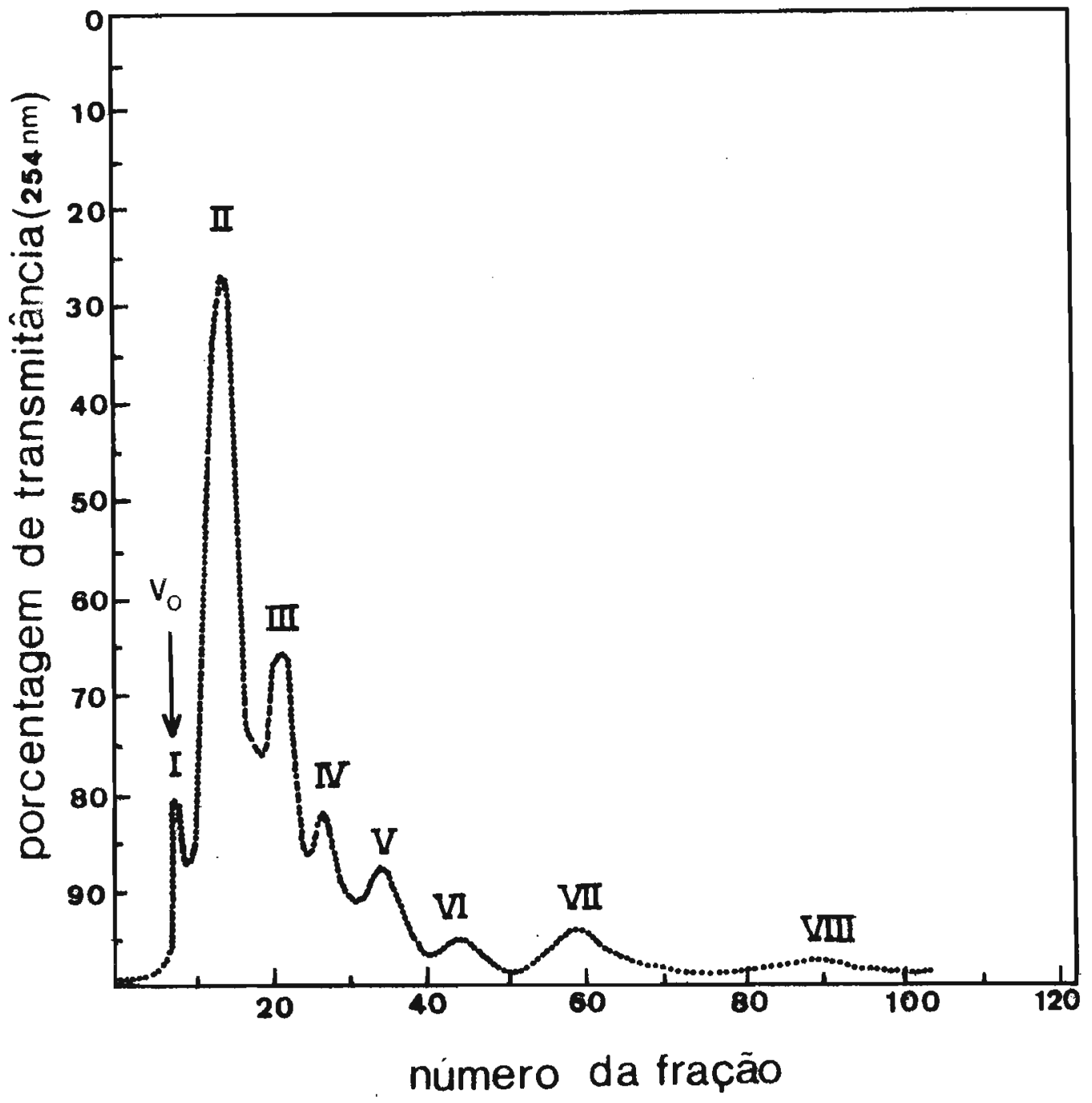

FIGURA 7: Diagrama de eluição de $0,5 \mathrm{ml}$ de Extrato Total em coluna de Sephadex G-25. A coluna fol equilibrada e eluida com acetato de aminio $0,02 \mathrm{M}$, fraçöes de $5 \mathrm{ml}$ foram coletadas a um fluxo de $1,6 \mathrm{ml} / \mathrm{mln}$. 


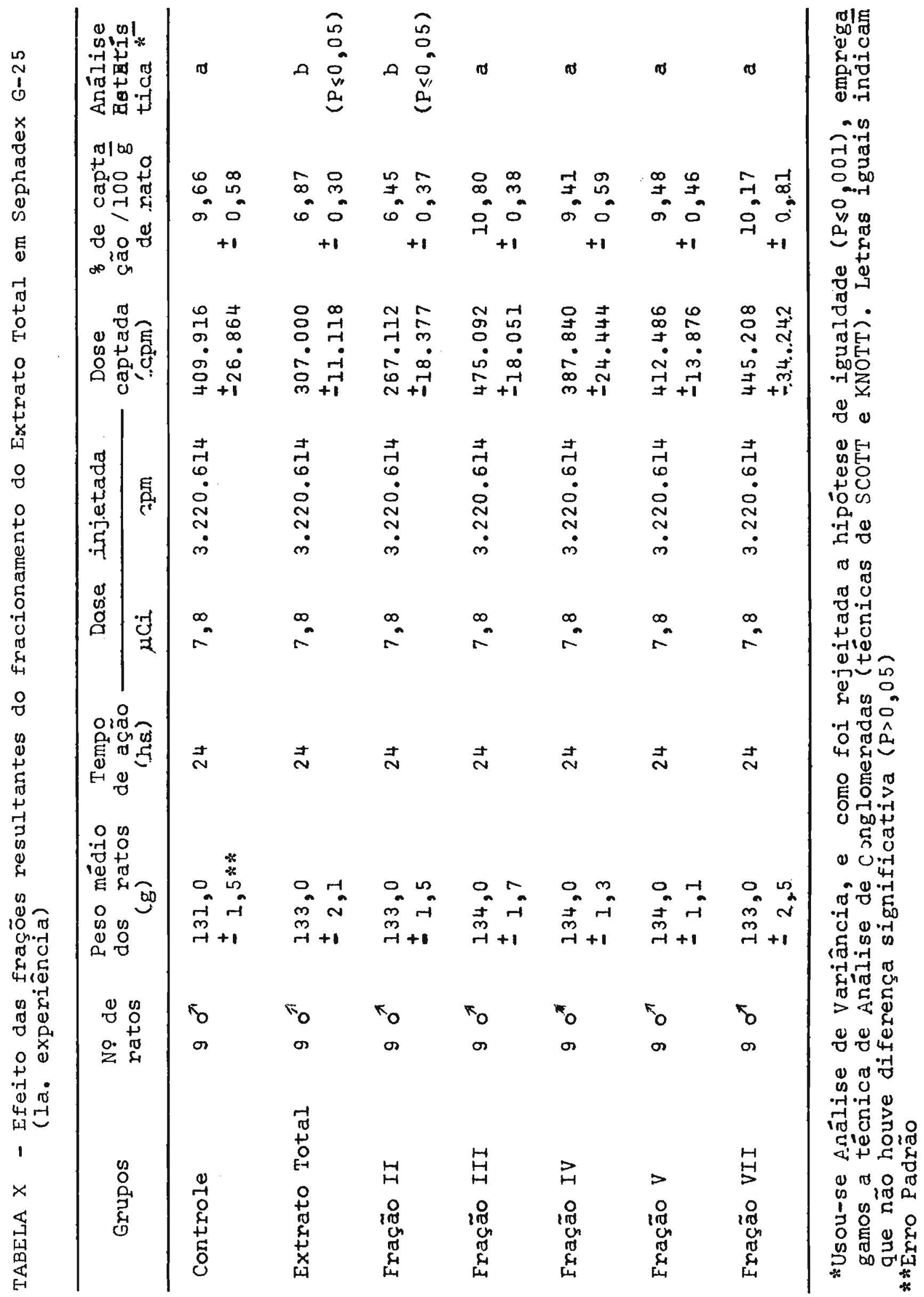




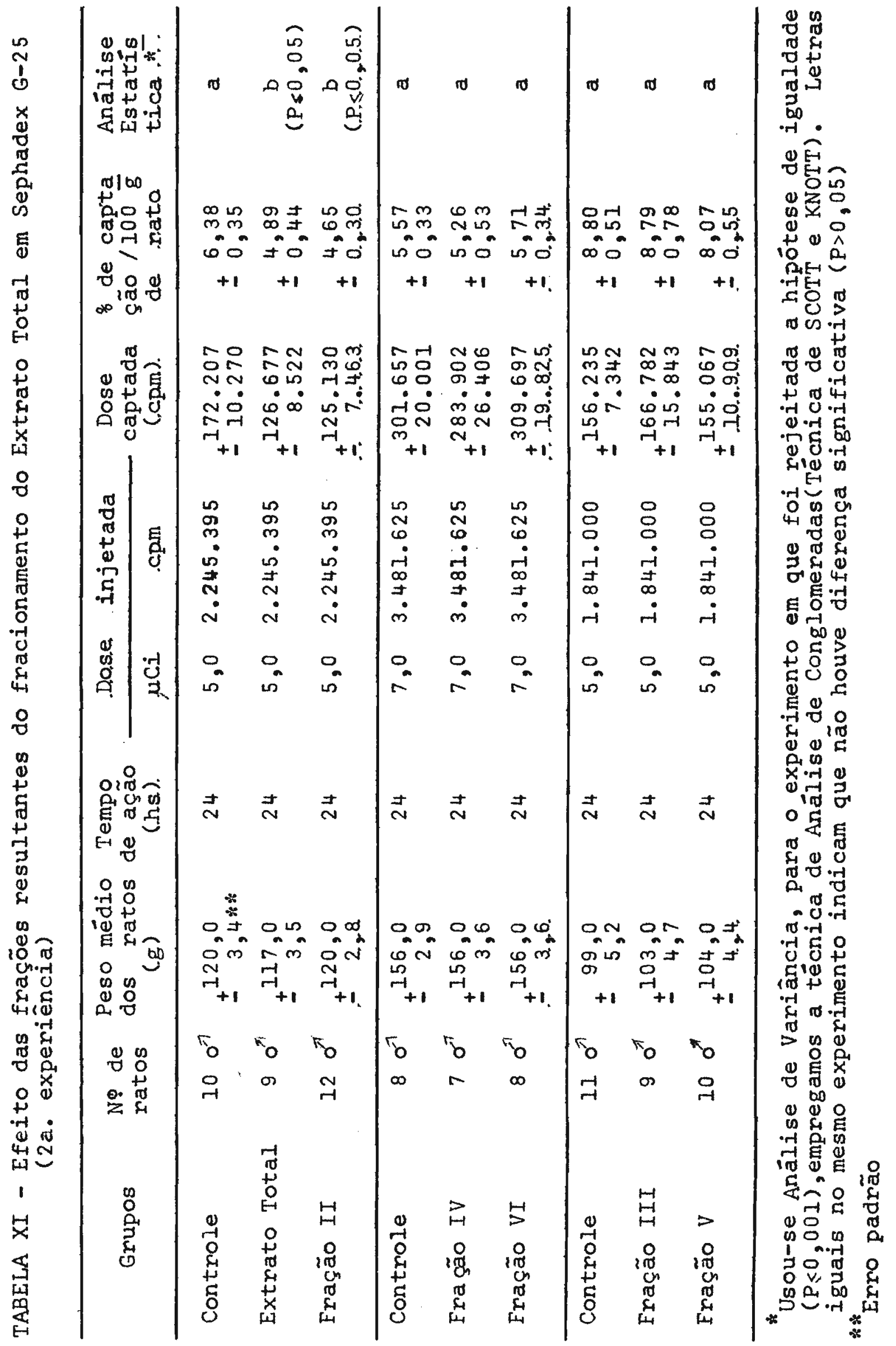


7.3 Testes Físico-Químicos de Identificação

A Fração II obtida por separação em coluna de Sephadex G-25, e que se mostrou ativa agindo na tireóide, foi subrnetida a alguns testes para se obterem indicações iniciais sobre a natureza química do composto em questão.

0 espectro de absorção evidenciou 2 pontos de máxima em $196 \mathrm{~nm}$ e $262 \mathrm{~nm}$ (Figura 8) semelhantes aos apresentados pelo Extrato Total. Os picos são indicadores da presença de peptídeos e flavonóides.

A fração, mesmo após fracionamento é formada por diversas substâncias dando reação positiva para glícides, grupo $\alpha$-amínico livre s substâncias fenólicas. Por cromatografia evidenciaram-se pelo menos 4 tipos de flavonóides, correspon dentes a 4 manchas nos cromatogramas (Tabela XII).

A Tabela mostra ainda testes efetuados com outras frações não ativas onde se verifica a presença de glícides e substâncias fenölicas em quase todas, mas em nenhuma a presen ça de grupo a-amínico livre.

Isso nos faz pensar na possibilidade da substância ter natureza peptídica. Outros autores $(20)$ identificaram um composto obtido da soja como sendo de nature za peptídica e de baixo peso molecular, o qual diminui a captação de ${ }^{13 I_{I}}$ na tireōide. Esse composto porēm era precipitável em etanol a $90 \%$ o que não parece ser o nosso caso (Ta bela IX) (a não ser que devessemos ter aquecido o Extrato Total antes do tratamento com etanol). Por outro lado, 0 mes- 


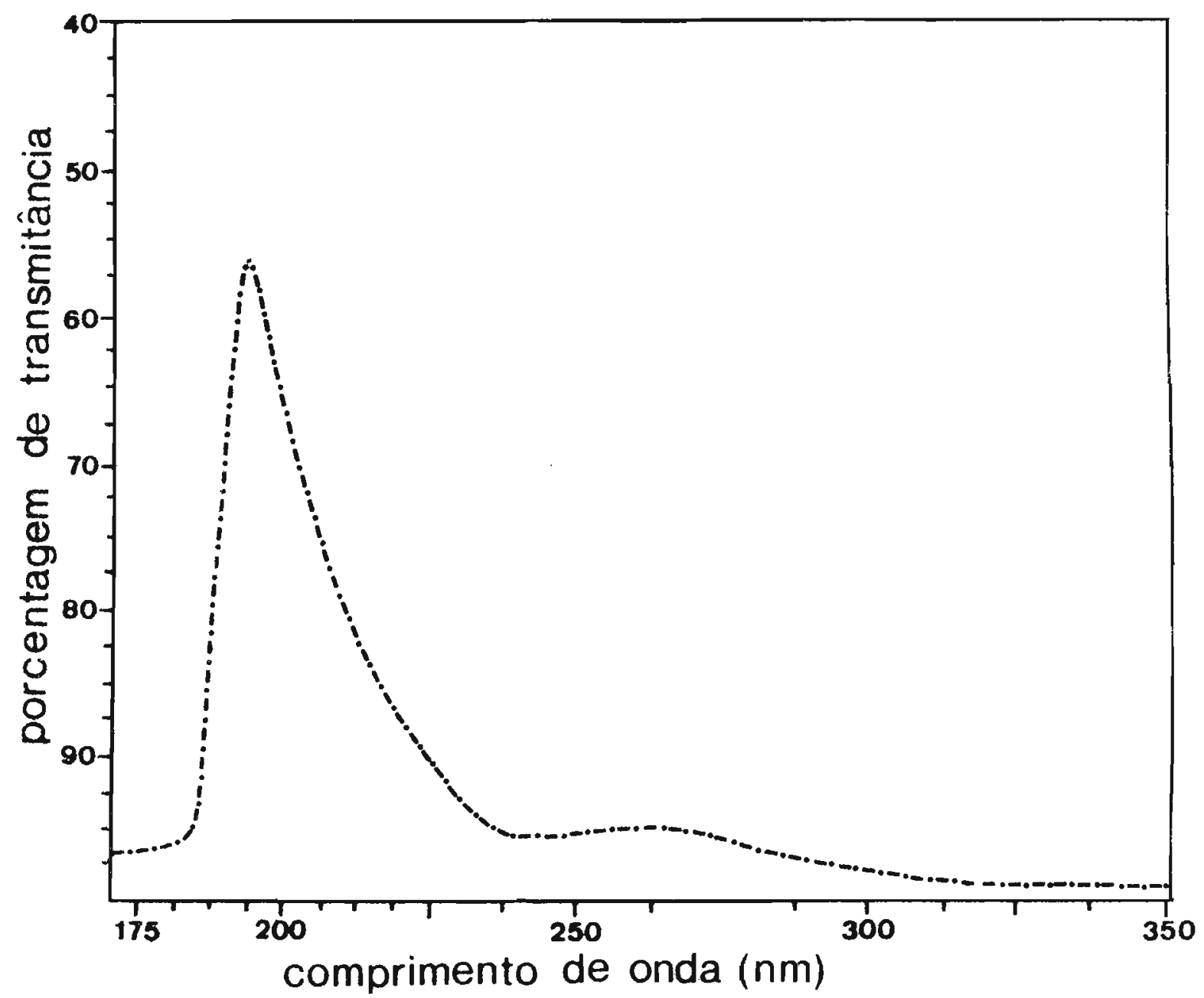

FIGURA 8: Espectro de absorção na falxa do ultravioleta da Fração II Sephadex G-25. 
.56.

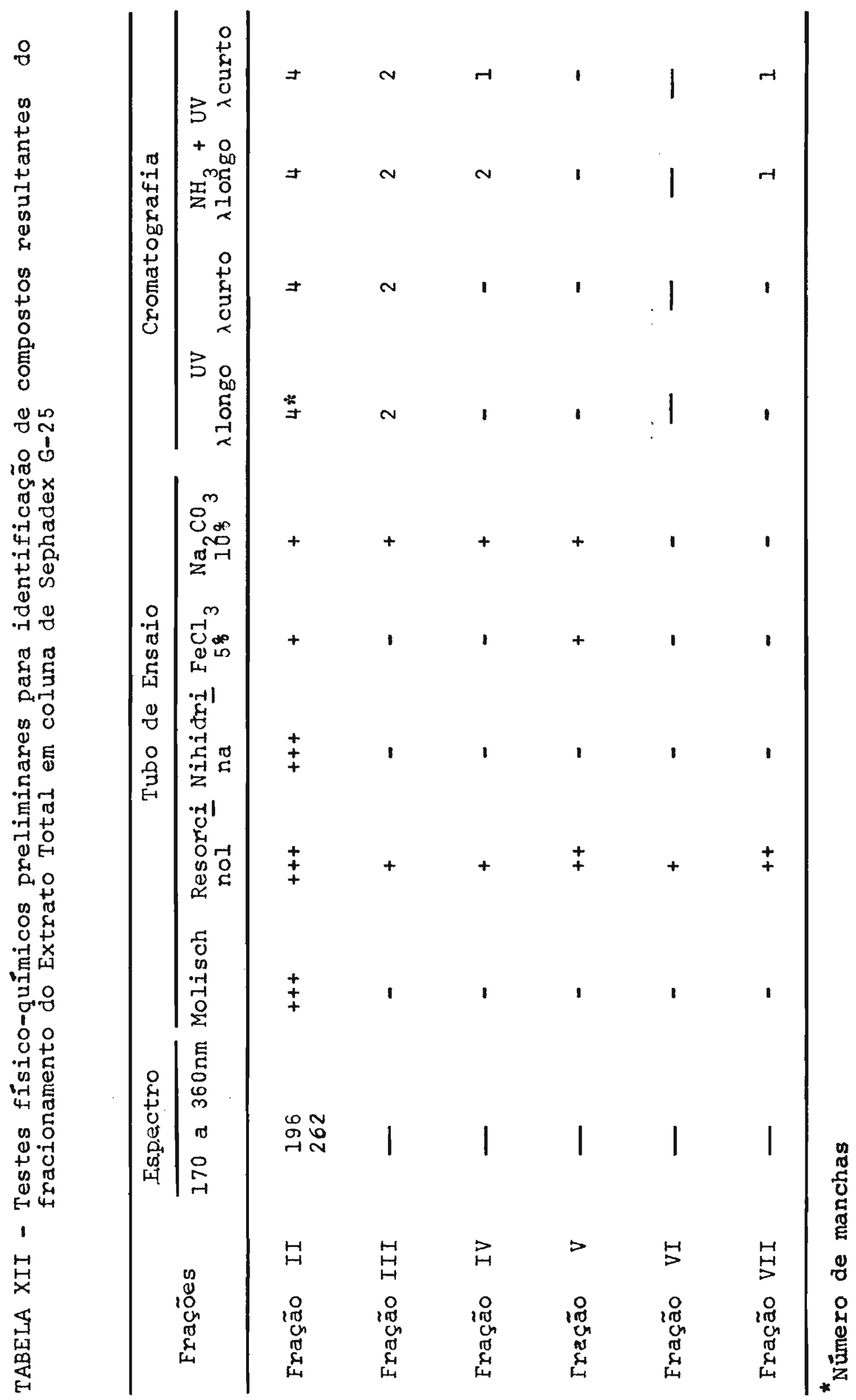


mo autor encontrou ação para soja não autoclavada nas 24 horas, o que não corresponde aos nossos resultados, estando uma possível comparação, a merecer melhores estudos.

Devemos comentar finalmente, com relação à ação de extratos aquecidos e não aquecidos que reunindo todas as experiências realizadas com Extrato Total, em alguns casos evi denciava-se a ação mesmo sem o aquecimento do Extrato Total (Tabela XIII).

A explicação parece ser devida a um aquecimento maior por ocasião do preparo do Extrato Total pois nesses casos ('on de havia ação sem autoclavagem prévia) o extrato tinha sido produzido em grandes quantidades (para ser adicionado à ração dos animais) o que pode tor causado um maior tempo de aquecimento.

Qualquer outra explicação que tentamos como: tempo de armazenamento da soja, idade do extrato, e proveniência da soja, não mostraram qualquer relação com o observado, tornando mais forte a explicação dada inicialmente. De qualquer forma o que nos parece relevante é que o aquecimento da soja provoca $\circ$ aparecimento de uma substância com ação na tireóide e não a destroi facilmente.

'Podemos resumir afirmando que existe na soja um "fator" que por aquecimento passa a ser ativo, aginndo de forma a diminuir a captação de ${ }^{13 I}$ I pela tireöide. Esse agente resiste a autoclavação por atê $I$ hora e estâ presente em diversos produtos comerciais de soja (item 7.4 )."

Na soja não tratada termicamente esse fator estä inibido, a sua ação é antagonizada por algun outro composto ou 


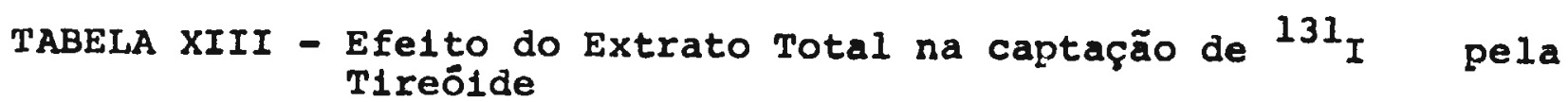

\begin{tabular}{|c|c|c|c|c|c|c|c|c|}
\hline \multirow{2}{*}{ Grupos } & \multirow{2}{*}{$\begin{array}{l}\text { No de } \\
\text { ratos }\end{array}$} & \multirow{2}{*}{$\begin{array}{l}\text { Peso médio } \\
\text { dos ratos } \\
\text { (g) }\end{array}$} & \multirow{2}{*}{$\begin{array}{l}\text { Tempo } \\
\text { de açäo } \\
\text { (hs) }\end{array}$} & \multicolumn{2}{|c|}{ Dose injetada } & \multirow{2}{*}{$\begin{array}{c}\text { Dose } \\
\text { captada } \\
\text { (cpm) }\end{array}$} & \multirow{2}{*}{$\begin{array}{l}8 \text { de capta- } \\
\text { qão / luo g } \\
\text { ratos }\end{array}$} & \multirow{2}{*}{$\begin{array}{l}\text { Pratarien } \\
\text { to esta= } \\
\text { tisticon }\end{array}$} \\
\hline & & & & $\mu \mathrm{Cl}$ & cpm & & & \\
\hline Controle & $9 d^{\prime}$ & $\pm^{101,0} 3,1 \ldots$ & 24 & 4,9 & 1.757 .648 & $\begin{array}{r}142.407 \\
\pm \quad 12.098\end{array}$ & $\begin{array}{r}8,03 \\
\pm \quad 0,68\end{array}$ & a \\
\hline Extrato Total & $11 \delta$ & $\begin{array}{r}107,0 \\
\pm \quad 3,7\end{array}$ & 24 & 4,9 & 1.757 .648 & $\begin{array}{r}153.728 \\
\pm \quad 9.310\end{array}$ & $\begin{array}{r}8,24 \\
+0,60\end{array}$ & a \\
\hline Controle & $10 \%$ & $\begin{array}{r}117,0 \\
4,6\end{array}$ & 24 & 5,5 & 2.059 .550 & $\begin{array}{r}251.994 \\
\pm \quad 15.840\end{array}$ & $\begin{array}{r}10,57 \\
\pm \quad 0,67\end{array}$ & $\mathbf{a}$ \\
\hline Extrato Total & $10 \%$ & $\begin{array}{r}120,0 \\
3,5\end{array}$ & 24 & 5,5 & 2.059 .550 & $\begin{array}{r}243.448 \\
12.620\end{array}$ & $\begin{array}{r}9,97 \\
\pm 0,76\end{array}$ & a \\
\hline Controle & 96 & $\pm \begin{array}{r}131,0 \\
1,5\end{array}$ & 24 & 7,8 & 3.220 .614 & $\begin{array}{r}409.916 \\
\pm \quad 26,864\end{array}$ & $\begin{array}{r}9,66 \\
\pm 0,58\end{array}$ & a \\
\hline Extrato Total & 98 & $\begin{array}{r}133,0 \\
2,1\end{array}$ & 24 & 7,8 & 3.220 .614 & $\pm \begin{array}{r}307.000 \\
11.118\end{array}$ & $\begin{array}{r}6,87 \\
\pm \quad 0,30\end{array}$ & $(P+0,05)$ \\
\hline Controle & $10 \delta$ & $\begin{array}{r}166,0 \\
\quad 3,0\end{array}$ & 24 & 8,2 & 3.420 .800 & $\begin{array}{r}192.750 \\
\pm \quad 12.701\end{array}$ & $\begin{array}{r}3,40 \\
\pm 0,26\end{array}$ & a \\
\hline Extrato Total & $10 \delta$ & $\begin{array}{r}165,0 \\
2,7\end{array}$ & 24 & 8,2 & 3.120 .800 & $\begin{array}{r}160.549 \\
\pm \quad 13.668\end{array}$ & $\begin{array}{r}2,84 \\
\pm 0,22\end{array}$ & $\mathbf{a}$ \\
\hline Controle & 108 & $\begin{array}{r}220,0 \\
3,4\end{array}$ & 24 & 5,0 & 2.245 .395 & $\begin{array}{r}172.207 \\
10.270\end{array}$ & $\begin{array}{r}6,38 \\
\pm 0,35\end{array}$ & $\Delta$ \\
\hline Extrato Total & $10 \delta$ & $\begin{array}{r}117,0 \\
\pm \quad 3,5\end{array}$ & 24 & 5,0 & 2.245 .395 & $\begin{array}{r}126.677 \\
\pm \quad 8.522\end{array}$ & $\begin{array}{r}4,89 \\
\pm 0,44\end{array}$ & $(P \leqslant 0,05)$ \\
\hline Controle & 80 & $\begin{array}{r}158,0 \\
\pm \quad 9,0\end{array}$ & 24 & 6,0 & 2.361 .625 & $\begin{array}{r}269.302 \\
\pm 25.704\end{array}$ & $\begin{array}{r}7.23 \\
\pm 0,63\end{array}$ & a \\
\hline Extrato Total & $8 d$ & $\begin{array}{r}155,0 \\
7,4\end{array}$ & 24 & 6,0 & 2.361 .625 & $\begin{array}{r}295.762 \\
\pm \quad 11.209\end{array}$ & $\begin{array}{r}5,47 \\
\pm \quad 0,47\end{array}$ & $\begin{array}{c}b \\
(P<0,05)\end{array}$ \\
\hline Controle & 76 & $\begin{array}{r}263,0 \\
8,1\end{array}$ & 24 & 7,0 & 3.340 .050 & $\begin{array}{r}632.107 \\
\pm \quad 58.504\end{array}$ & $\begin{array}{r}11,93 \\
\pm 1,25\end{array}$ & a. \\
\hline Extrato Total & $0 d$ & $\pm \begin{array}{r}161,0 \\
6,6\end{array}$ & 24 & 7,0 & 3.340 .050 & $\begin{array}{r}530.335 \\
\pm 56.650\end{array}$ & $\begin{array}{r}9,97 \\
1,45\end{array}$ & $a$ \\
\hline
\end{tabular}

- Jả descrito nas tabelas anteriormente apresentadas.

" Erro padrão 
ele se encontra na forma de um precursor.

Nesse último caso o fator só se formava com o aquécimento da soja, mas de qualquer forma a ingestão de soja pro cessada levaria a ingestão desse agente.

Testes para maior purificação estão em elaboração; jä verificamos por exemplo que um tratamento prévio por carvão é efetivo na eliminação de vários flavonóides (eliminação do pico em $260 \mathrm{~nm}$ ) bem como glícides. Colunas de poliestireno sulfonada e Dowex $50 \mathrm{~W} \times 8$ (20-50 Mesh U.S.) eluidas por gradiente de acetato de piridina parecem dar bons resultados na separação da Fração II.

7.4 Presença do Fator em Diferentes Produtos Comerciais de Soja

Os nossos resultados mostram a existência de fato, de um fator ativo sobre a tireöide, mesmo na soja autoclavada, de elevada resistência têrmica, passível mesmo de se formar du rante o aquecimento.

Como värios produtos obtidos da soja e de seus derivados são atualmente comercializados e consumidos por diversos grupos etários, resolvemos testar a ação de alguns deles sobre a tireóide.

Todos os produtos testados: Concentrados Protéicos, $\mathrm{F} \underline{\mathrm{a}}$ rinha Tostada de Soja e Leite de Soja, mostraram-se ativos na depressão da captação de ${ }^{131}$ I pela tireóide de ratos (Tabela XIV). Esses resultados confirmam a adequação da técnica que 


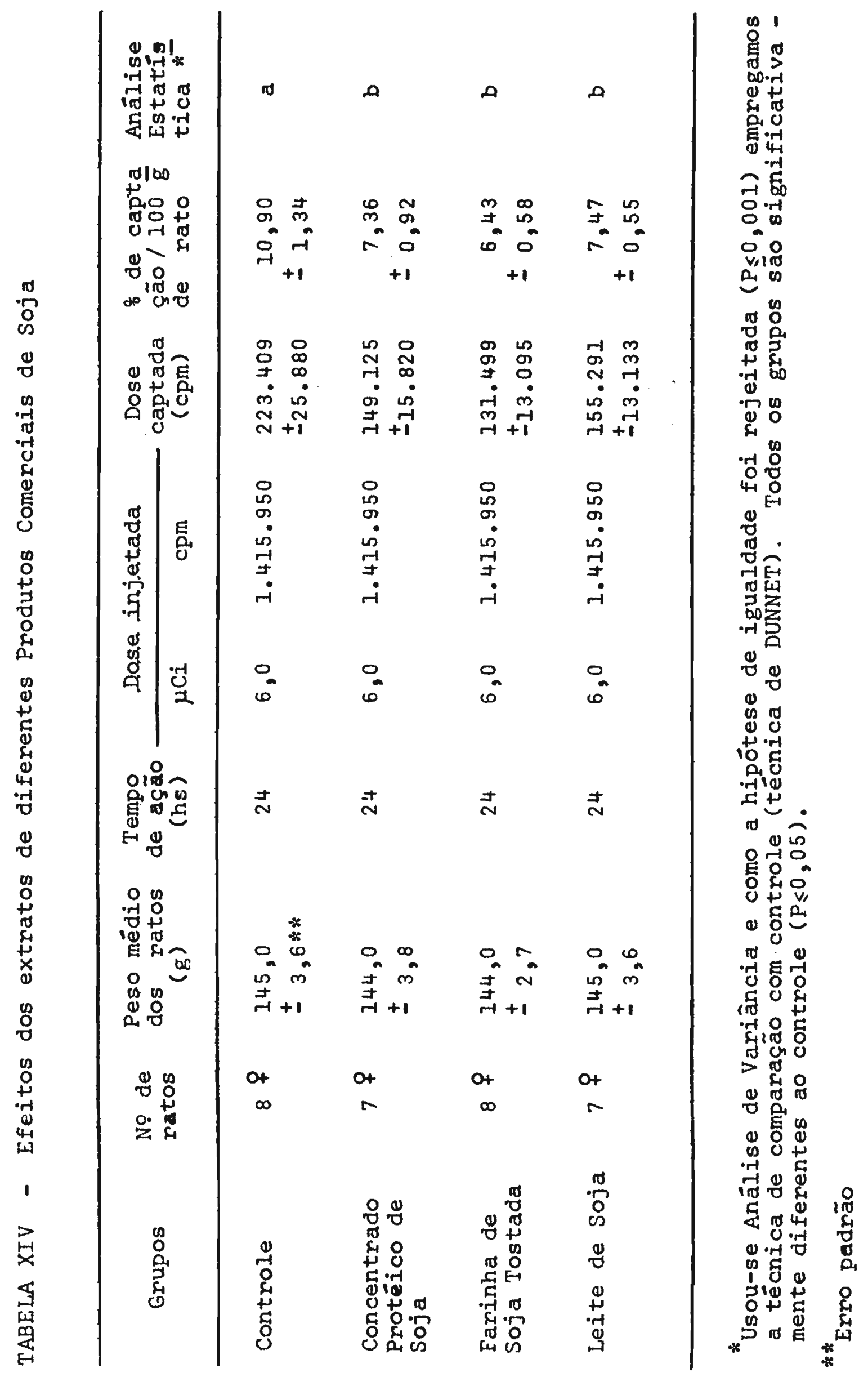


empregamos para avaliar a presença dessas substâncias e as in dicariam em um controle de qualidade:ou fiscelização futura. Por outro lado ficou patente que, mesmo o processamen to industrial, não é capaz de destruir a substância ativa sen do que, com base nos resultados jâ descritos, a mesma pode ser inclusive "liberada" ou "formada" pelas operações de tostagem, pasteurização, etc.

Acreditamos, também, que o processamento posterior a nível doméstico não conseguirá destruir totalmente essa substância, pois como vimos é capaz de resistir a autoclavagem a $1 \mathrm{~atm}$. $121^{\circ} \mathrm{C}$ por 1 hora; tratamento a que a maioria dos produ tos de soja dificilmente seriam submetidos.

Resta saber qual a consequência da ingestão crônica desses alimentos ou seja qual o significado nutricional.

\subsection{Ensaios Semicrônicos}

Através dos ensaios agudos constatamos, na soja autoclavada, a presença de um fator capaz de inibir a captação de ${ }^{131}$ I pela tireöide, desde 6 horas apōs a administração,man tendo-se a ação pelo menos 24 horas depois.

Com intuito de obter dados sobre a ação. a longo pra zo, estabelecer o mecanismo de ação do fator e inferir sobre - significado nutricional da sua ingestão realizamos dois ensaios semicrônicos, tanto com fraçōes de soja crua como autoclavada. 
o tratamento pelo calor foi necessārio, não só para lị berar a ação do fator, como para eliminar a interferência de outras substâncias antinutricionais.

Sabe-se pela literatura que a soja crua e seus produtos de fracionamento contëm uma sërie de fatores antinutricionais como hemaglutininas ${ }^{(56)}$, inibidores de crescimento ${ }^{(39)}$ $(40)(56)$, antitripsinas $(23)(24)(39)(40)(56)$ bem como outros não ainda bem identificados (40)(56).

0 primeiro ensaio semicrônico teve duração de 16 dias, partindo-se de ratos com peso inicial ao redor de $86 \mathrm{~g}$; no 'se gundo conseguimos preparar material para 29 dias de experi mento e iniciamos com ratos mais jovens que tinham peso ini cial de $59 \mathrm{~g}$.

0 primeiro ensaio foi realizado com 6 grupos experi mentais, sendo que em três deles testamos produtos não auto clavados de soja (Tabela I) que foram: Farinha de Soja Desengordurada (FSD), Residuo (R) ou Residuo Autoclavado + Extrato Bruto $(R A+E B)$. Os outros grupos foram os correspondentes au toclavados ou seja: Farinha de Soja Desengordurada Autoclavada (FSDA), Residuo Autoclavado (RA) ou Residuo Autoclavado + Extrato Bruto Autoclavado (RA + EBA).

Verifica-se facilmente pela Tabela XV, que nos gru pos que recebiam rações contendo as frações não autoclavadas de soja, obteve-se crescimento menor e menor coeficiente de eficăcia alimentar indicando a presença, em todos eles, de 'fa tores inibidores de crescimento.

O coeficiente de eficăcia alimentar, para as fraçōes autoclavadas, foi o mesmo para todas, o que não aconteceu no 


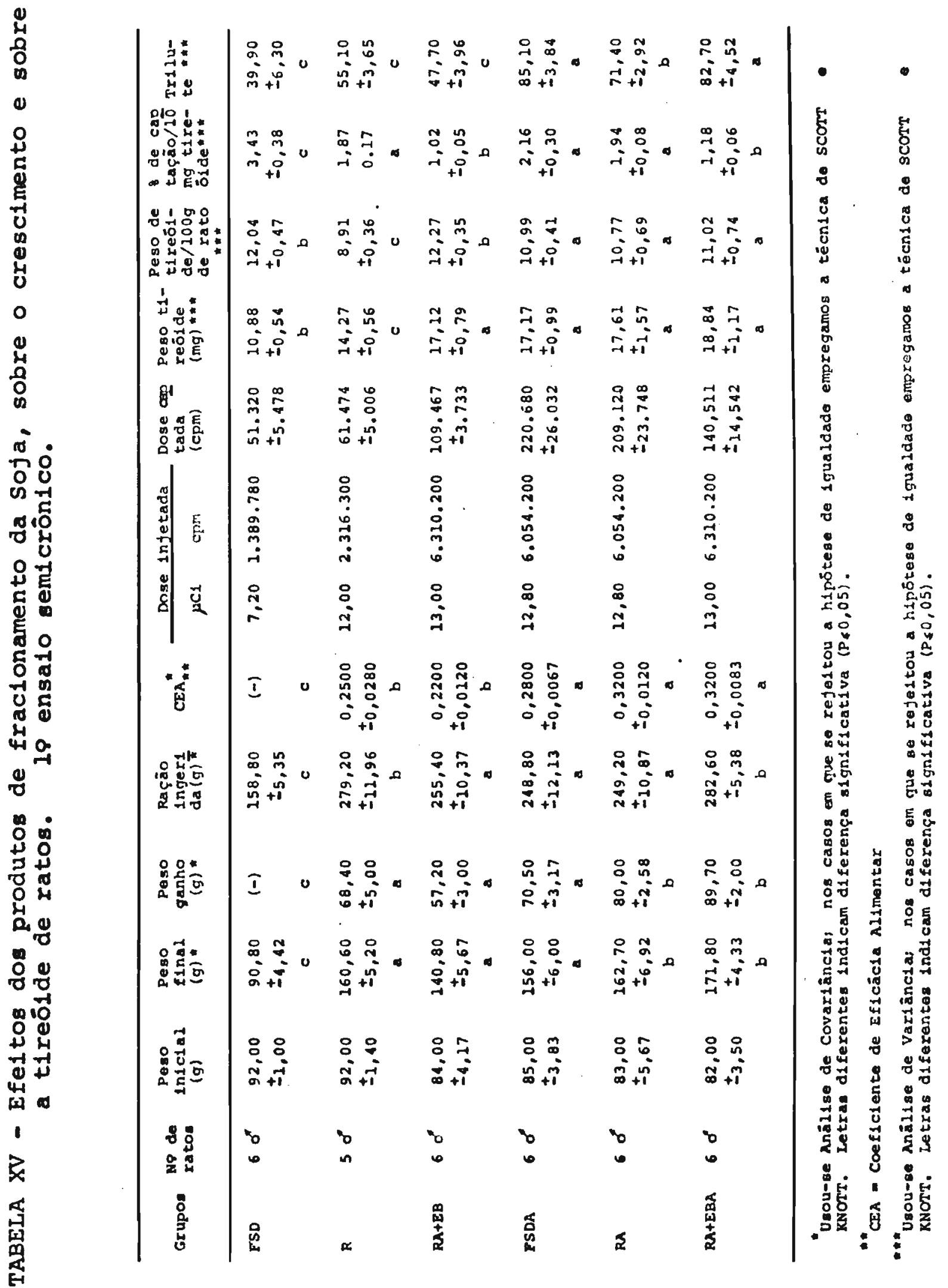


caso das não autoclavadas.

Vê-se, ainda, pela Tabela que o grupo com FSD teve ooe ficiente de eficäcia alimentar negativo ao passo que os gru pos $R \cong R A+E B$ foram positivos, apesar de serem inferiores aos dos grupos correspondentes que receberam tratamento térmi co; esses resultados mostram a existência, mesmo nessas frações, de fatores antinutricionais que como fica demonstradó fo ram destruidos pelo tratamento térmico.

Sobre a possível influência da substância em estudo no crescimento, pode-se dizer que como os grupos FSDA e RA + EBA contêm o fator ativo sobre a tireóide e como o crescimento fai - mesmo em ambos, pelo menos em 16 dias, esse fator não conise gue influir no crescimento.

Jä na segunda experiência os resultados parecem iridi car uma diminuição de crescimento nos grupos FSDA e RA + EBA en relação a RA (Tabela XVI).

Nesse caso a explicação pode estar no maior tempo de ação do fator ( 29 dias) e na maior sensibilidade do ensaio,ja que usamos ratos mais jovens.

Parece, portanto, possível que o fator consiga em con dições especiais, reduzir o crescimento e mais estudos deve rão ser feitos para confirmar os resultados, com rações modeIo de caseína, adicionadas do fator purificado e livre mesmo de traços de outros possiveis antinutrientes.

Essa diferença de efeitos, em função do prazo de ação foi observada, tambëm, para os resultados referentes à $\&$ de captação/10mg de tireōide. Após 16 dias, o fator autoclavado ou EBA presente na ração é capaz de diminuir a captação - (Ta 


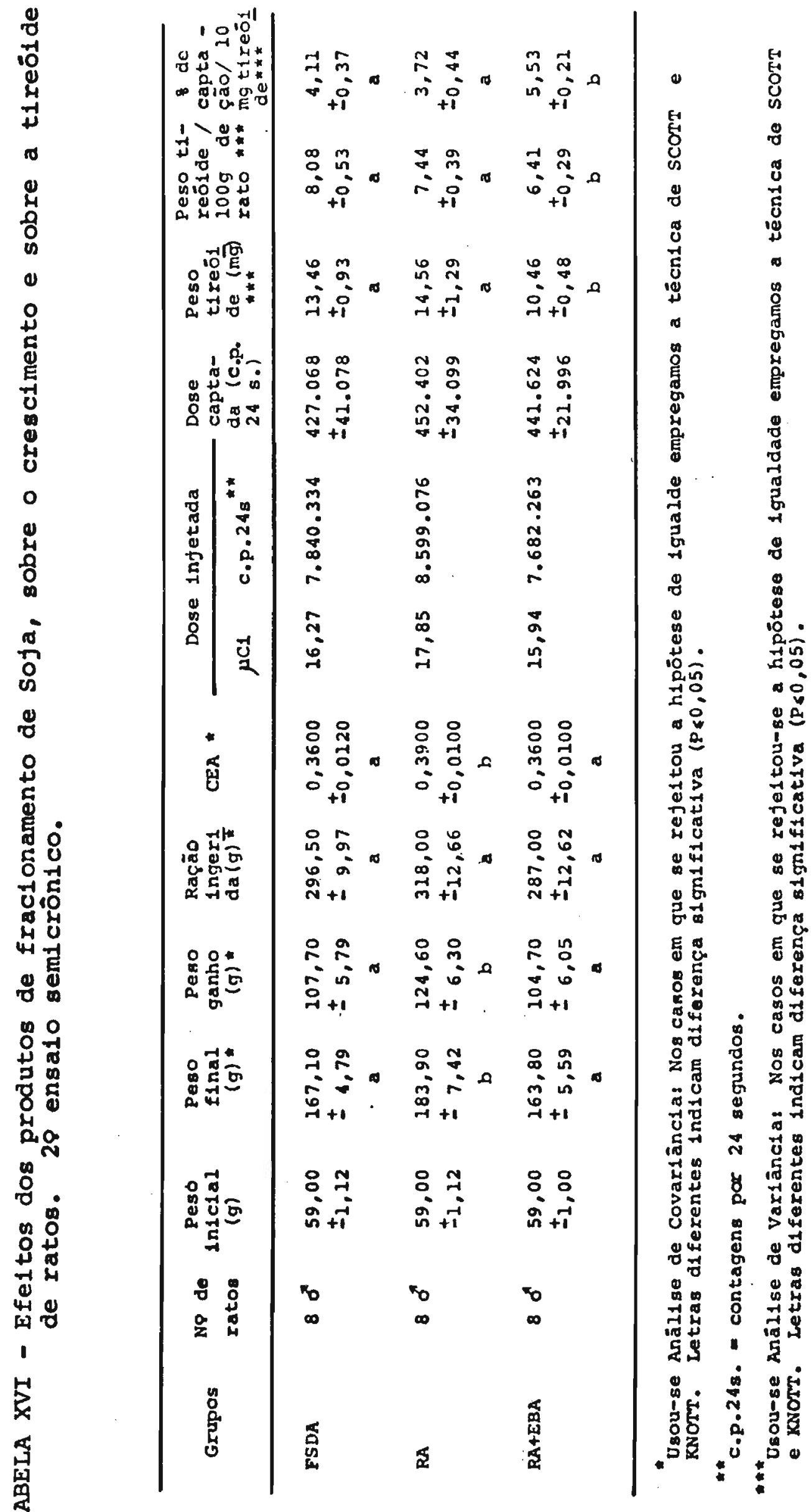


bela XV); jầ após 29 dias o efeito $\vec{e}$ inverso havendo um aumen to da mesma. Parece haver uma adaptação sobre a qual volta remos a falar adiante (Tabela XVI).

Os resultados referentes à captação de ${ }^{13 I^{1}}$ / $10 \mathrm{mg}$ de tireóide permitem explicar, também, as divergências da litera tura quanto à ação da soja sobre a tireóide; é evidente que fatores antinutricionais interferiram com os resultados de au tores que testaram a soja crua $(4)(12)(19)(20)(27)(44)(50)(53)$, tornando, assim, difícil uma avaliação segura sobre quais as substâncias responsāveis pelos efeitos observadus.

o grupo com FSD, por exemplo, que cresceu menos, teve captação aumentada, comparada com o correspondente autocla vado que, pelos ensaios agudos sabemos que contém o fator capaz não de aumentar mas de deprimir essa ação.

Comparando-se o grupo $R A+E B$ com $R$, observa-se que na presença de EB e portanto do fator, houve uma menor captação; como o crescimento dos animais desses grupos foi semelhan te pode-se atribuir essa diferença à ação do fator em estudo que inclusive teria provocado um aumento no peso da tireóide/ $1100 \mathrm{~g}$ de rato de 8,91 para $12,27 \mathrm{~g}$.

O resultado, porém, não era esperado, jâ que seria ne cessârio a autoclavagem prévia do EB para a ativação do fator. E possivel que o fator presente no Extrato Bruto, pela ação crônica sofresse uma ativação semelhante à causada pe Io aquecimento ou, mesmo, que haja intenferência de outras substâncias $(38)(39)(40)$ tóxicas presentes nessa fração.

E relevante ainda, comentar o fato do Coeficiente de Eficácia Alimentar para os grupos $R A+E B$ e $R$ ser muito supe- 
rior ao do FSD.

Como o grupo $R$ teve um Coeficiente de Eficäcia Alimen tar de 0,25 e 0 FSD negativo, era de se esperar que o grupo que contém RA (cujo CEA isolado era de 0,32 ) adicionado de Ex tratato Bruto tivesse também CEA negativo, causado pelos fatores antinutricionais presentes no $E B$.

Tal não aconteceu e a explicação pode estar relacióna da a problemas de digestibilidade; 0 grupo $R$ tem menos fato res tōxicos mas baixa digestibilidade, jā o grupo $R A+E B$ tem mais fatores tóxicos mas maion digestibilidade, efeitos que se compensariam. 0 apoio para a explicação se encontra nos estudos de LIENER ${ }^{(24)}$ sobre digestibilidade de soja crua e aquecida e nos estudos de SCHINGOETHE e col. (39), sobre inibí dores trípticos e de crescimento encontrados na soja crua.

A situação dos hormônios séricos tireoidianos, no 10 ensaio semicrônico foi obtida pelo sistema Trilute.

Pela Tabela XV observamos que o Indice Trilute no gru po de animais que receberam frações de soja não autoclavadas foi aproximadamente $41 \%$ inferior ao dos animais que receberam soja autoclavada, indicando que existe uma diminuição na quan tidade de hormônios circulantes nesse grupo.

Verifica-se claramente pela Tabela XV, que $\circ$ agente causador dessa diminuição não foi o fator em estudo, pelo menos nos grupos FSD e RA + EB, pois o grupo que recebeu $R A$ e portanto isento do fator ativo, manifestou um indice inferior as das outras duas rações autoclavadas (FSDA e RA + EBA) que - contém. Concluímos que os fatores antinutricionais presentes na soja crua e em seus produtos de fracionamento causaram 
essa diminuição dos índices Trilute.

Resultados semelhantes foram, tambêm, observado por KONIJN e col. (19) que, porém, responsabilizaram o fator bocio gênico como o agente causador da diminuição desse indice, a nosso ver erroneamente pelo que jā expusemos:.

No nosso caso o fator aumenta e não diminui os hormô nios circulantes como se depreende pela Tabela XV ao comparar os grupos que receberam frações autoclavadas FSDA e RA + EBA com o controle RA.

No segundo ensaio (Tabela I) o experimento foi realizado em três grupos de animais com os quais testamos aperas ra ções preparadas com as frações autoclavadas (FSDA, RA + EBA , RA) para eliminar a ação dos fatores tôxicos que não aquele em estudo que, como vimos, dificultavam a interpretação dos resultados.

Pela Tabela XVI observamos que a medida da porcenta gem de captação/10 mg de tireöide no grupo que recebeu em sua ração $R A+E B A$ comportou-se de modo oposto ao esperado, obser vando-se um aumento nesse indice: Tanto no ensaio crônico anterior, com soja autoclavada, como nos ensaios agudos com ET autoclavado, a porcentagem de captação diminuiu em relação ao grupo controla.

O extrato bruto autoclavado (EBA) utilizado nesse ex perimento foi testado em animais (ensaio agudo), antes de ser incorporado à ração, e manifestou uma diminuição de 58\% na porcentagem de captação/100g de rato em relação ao grupo controle (após 24 horas).

A diminuição inicialmente provocada pelo fator na 
porcentagem de captação e posteriormente seu aumento, quando ensaiado a longo prazo ( 29 dias), nos fazem pensar em um méca nismo de compensação glandular provocado pela baixa quantidade de iodo que inicialmente entra na glândula ${ }^{(51)}$ devido ao bloqueio da entrada do mesmo.

Para uma melhor interpretação desses fatos a nível glandular, realizamos as cromatografias do hidrolisado de tireóide e dosamos os hormônios séricos atravēs radioimunoen saio.

Os resultados obtidos pelos ensaios acima estão expos tos na Tabela XVII e podem ser resumidos da seguinte forma, comparando-se os grupos RA (controle) com RA + EBA e com FSDA:

1 - Para os hormônios tireoidianos (radioativos) consta tam-se as tendências:
a) Aumento de $T_{3}$ como de $T_{4}$
b) Aumento de MIT
C) Diminuição de DIT
d) Diminuição de $\mathrm{I}^{-}$
e) Aumento da relação MIT/DIT
f) Diminuição da relação $\mathrm{T}_{3} / \mathrm{T}_{4}$
g) 0 aumento de $\mathrm{T}_{4} \vec{e}$ maior do que $\circ$ de $\mathrm{T}_{3}$

2 - Para os hormônios séricos observou-se a não mudança dos niveis de $\mathrm{T}_{4}$ e $\mathrm{T}_{3}$, apesar da tendēncia à reduçāo de $\mathrm{T}_{3}$ que não foi, porêm, significativa.

Sabemos que a administração do fator em ensaios agu dos de 24 horas, provoca un abaixamento na captação de ${ }^{13 I_{I}}$, 
TABELA XVII - Efeitos dos produtos de fracionamento da Soja,na síntese dos hormônios tiroideanos: 28 ensaio se micrônico.

\begin{tabular}{|c|c|c|c|}
\hline Doseamentoos & FS.DA & $R A$ & $R A+E B A$ \\
\hline $\mathrm{T}_{4} \operatorname{sérico(ug/ml)}$ & $\begin{array}{c}5,53 \\
\pm 0,25 \\
a *\end{array}$ & $\begin{array}{c}5,90 \\
\pm 0,29 \\
a\end{array}$ & $\begin{array}{c}5,90 \\
\pm 0,40 \\
a\end{array}$ \\
\hline $\mathrm{T}_{3} \operatorname{sérico}(\mathrm{ng} / 100 \mathrm{ml})$ & $\begin{array}{c}0,98 \\
+0,15 \\
a\end{array}$ & $\begin{array}{c}0,94 \\
\pm 0,10 \\
a\end{array}$ & $\begin{array}{c}0.74 \\
\pm 0.06 \\
a\end{array}$ \\
\hline
\end{tabular}

Distribuição porcentual dos hormônios marcados $\left(13 I_{I}\right)$ e de seus precursores na tireóide

$\mathrm{NaI}$

$$
\begin{array}{ccc}
12,94 & \pm 18,92 & 12,75 \\
1,40 & \pm 1,18 & \pm 1,43
\end{array}
$$

Monoiodotirosina (MIT)

$\begin{array}{ccc}18,53 & 0,16,15 \\ 0,43 & \pm 0,85 & \pm 18,61 \\ a & b & a, 84\end{array}$

Diiodotirosina (DIT)

$$
\begin{array}{ccc}
45,14 & 1,11 \\
1,11 & \pm 0,54 & \text { bc }
\end{array} \quad \begin{gathered}
46,60 \\
1,00
\end{gathered}
$$

Tiroxina $\left(\mathrm{T}_{4}\right)$

$\begin{gathered}11,94 \\ 2,12 \\ a\end{gathered} \quad \begin{gathered}4,81 \\ b\end{gathered} \quad \pm \begin{gathered}12,00 \\ 1,58\end{gathered}$

Triodotironina $\left(\mathrm{T}_{3}\right)$

$\begin{gathered}2,29 \\ 0,32 \\ a\end{gathered} \quad \begin{gathered}1,16 \\ 0,14 \\ b\end{gathered} \quad \pm \begin{aligned} & 2,01 \\ & 0,19\end{aligned}$

MIT / DIT

$\begin{array}{cc}0,41 \\ 0,01 \\ a\end{array} \quad \begin{gathered}0,33 \\ 0,01 \\ b c\end{gathered} \quad+\begin{gathered}0,40 \\ 0,03 \\ a c\end{gathered}$

$\mathrm{T}_{3} / \mathrm{T}_{4}$

$\begin{gathered}0,19 \\ 0,01 \\ a\end{gathered} \quad+\begin{gathered}0,23 \\ 0,03 \\ a b\end{gathered} \quad+\begin{gathered}0,17 \\ 0,01 \\ a c\end{gathered}$

*Usou-se Análise de Variância: Nos casos em que se rejeitou a hipötese de igualdade empregamos a têcnica de FISHER. Letras diferentes indicam diferença significativa $(P \leqslant 0,05)$. 
no entanto, em ensaios semicrônicos (29 dias), é capaz de pro mover efeito inverso ou seja aumento na captação (Tabela XVI). Comparando os nossos resultados, referentes à capta ção e a mudança dos hormônios tireoidianos verificamos que a ação do fator não corresponde à de nenhuma das outras substân cias descritas na literatura e que agem na tireóide.

Assim, os percloratos e tiocianatos ${ }^{(58)}$ provocam dimi nuição na captação e tambêm redução na velocidade de síntese de todos os hormônios glandulares sem alterarem as relações MIT/DIT e $\mathrm{T}_{3} / \mathrm{T}_{4}$.

Parece, também, que não age nas peroxidases tireoidia nas inibindo a organificação do iodo, como é o caso das tiona midas em geral ${ }^{(58)}$, aromāticos ${ }^{(58)}$ e alguns flavonóides (18) (29). Os flavonöides, porëm, poderiam ser responsabilizados em parte pela ação na glândula, através de outro mecanismo di ferente do citado, pois além de estarem presentes, como já foi observado, na fração II (Sephadex G-25), sabe-se que podem diminuir a captação de ${ }^{13 I_{I}}$ (42).

0 nosso fator age, tambëm, diferentemente daquele iso lado por KONIJN e col. (20) que observaram uma diminuição na captação e também uma diminuição na organificação de ${ }^{13}$ I; "de vemos levar em consideração, porém, que esses autores testa ram a ação do fator apenas "in vitro", alêm disso não era autoclavado, mas mesmo assim, agia após 24 horas.

Para o nosso caso, observamos inicialmente que o fator provoca uma menor incorporação de ${ }^{13 I^{2}}$ e após 29 dias dá-se justamente o inverso (aumento na porcentagem de captação). Isso nos leva a crer que, pela diminuição inicial da incorpo- 
ração de iodo, a glândula, através de um mecanismo de compensação provocado pela deficiência de iodo organificado, aumenta sua capacidade em incorpora-10(51). A depleção inicial de iodo provocaria uma diminuição na síntese dos hormônios, e a partir do momento em que a disponibilidade de iodo aumentas se dar-se-ia un aumento na velocidade de sintese dos mesmos; esse fato é observado indiretamente pela diminuição na porcen tagem de ${ }^{13 I}$ I não onganificado e no aumento das poncentagens de $M I T, T_{3}$ e $T_{4}$ radioativos.

A diminuição na porcentagem de DIT radioativo encon tra explicação no seguinte fato: como esse precursor contém mais ätomos de iodo em sua estrutura e como ele participa em maior quantidade na síntese dos hormônios tireoidianos, seria então o primeiro a ter sua concentração diminuida como con'se quência da diminuição da incorporação de iodo, e, posterior mente como consequência do aumento da velocidade na sintese de $\mathrm{T}_{3}$ e $\mathrm{T}_{4}$

Existe, também, a possibilidade desse fator agir na síntese de DIT a nível das peroxidases especificas, provocando uma diminuição do mesmo, mas pelos nossos resultados não observamos, como decorrência, um abaixamento na concentração de $\mathrm{T}_{3}$ e $\mathrm{T}_{4}$ na glândula bem como no soro.

A fim de obtermos conclusões mais concretas relaciona das com o mecanismo de ação do fator, serä necessärio anali sar sua influência a nível glândular e sêrico através de expe rências efetuadas a longo prazo, com dados coletados em diferentes intervalos de tempo. 


\section{CONCLUSOES}

1. Existe na soja autoclavada um fator capaz de diminuir, entre 6 e 24 horas após sua administração, a captação de iodo pela tireöide de ratos; esse fator não foi porém encontrado em soja crua.

2. Esse fator existe tambëm em produtos comerciais como: Concentrado Protéico de Soja, Farinha de Soja Tostada e Leite de Soja e é resistente ao tratamento térmico a $121^{\circ} \mathrm{C}$ por 60 minutos.

3. Em ensaios semicrônicos com animais, ele pode provocar tanto aumento como diminuição da captação dependendo do tempo de ação. Nessas condições é capaz de aumentar a velocidade de sintese da Monoiodotirosina, TRiodotironina e Tiroxina, de diminuir a da Diiodotirolna e de causar queda no radioiodo não organificado na tireóide. Dependendo do tempo de ação é capaz inclusive de provocar um aumento dos hormônios séricos. 
I - ASTWOOD, E. B.; BISSELL, A.; HUGHES, A. M. - Further studies on the chemical nature of compounds which inhibit the function of the thyroid gland. Endocrinology, Springfield: :37:456-481, 1945 .

2 - ASTWOOD, E.B.; GREER, M.A.; ETTLINGER, M.G. - L-5-vinyl-2-thio-oxazolidone and antithyroid compound from yellow turnip and from brassica seeds. 'J.biol.Chem. Baltimore, :181:121-130, 1949 .

3 - BECK, R.N. - Soy flour and fecal thyroxine loss in rats. - Endoocrinology, Springfield,: 62:587-592, 1958.

4 - BLOCK, R.J. \& MANDL, R.H. - The curative action of iodine on soybean goiter and the changes in the distribution of iodoamino acids in the serum and in thyroid gland digests. Arch.Biochem., New York,: 93:15-24, 1961.

5 - DAWSON,R.M.C.; ELLIOTT, D.C.; ELLIOTT, W.H.; JONES, K. M. - Data for biochemical research. 2.ed. London, Oxford University Press, 1974. $654 \mathrm{p}$.

* De acordo com as normas preconizadas pela ASSOCIAÇAO BRASILEI RA DE NORMAS TECNICAS (ABNT). As abreviaturas dos titulos de periódicos de acordo com o WORLD MEDICAL PERIODICALS, 3 ed. New York, 1961. 
6 - DAXENBICHLER, M. E.; VAN ETTEN, C.H, ; SPENCER, G.F. Glucosinolates and derived products in cruciferous vegetable. Identification of organic nitriles from cabbage. J.Agric.Food Chem., Washington, 25:121-124, 1977.

7 - FEDERE, W.T. - Experimental design., New York, MacMillan, 1955. 544 p.

8 - FOX, M.R.S. \& BRIGGS, G.M. - Salt mixture for purified-type diet. III. An improved salt mixture for chicks. J.Nutr., Philadelphia, :72:242-250, 1960 .

9 - GONTZEA, I.; FERRANDO, R.; SUTZESCO, P. - Substances antinutritives naturelles des aliments. Paris, Vigot Frèves, 1968. p.101-123.

10 - GREER, M.A. Nutrition and goiter. Physiol. Rev., Washington: $30: 513-548,1950$.

11 - GREER, M.A. - II. Thyroid hormones. The natural occurren ce of goitrogenic agents. Recent Progr. Hormone Res., New York: :18:187-219, 1962 .

12 - HALVERSON, A.W.; ZEPPLIN, M.; HART, E.B. - Relation of iodine to the goitrogenic properties of soybeans. 'J. 'Nutr., Philadelphia, :38:115-129, 1949 .

13 - HOPKINS, C. Y. - A sulfur-containing substance from the seed of Coringia orientalis. Canad J.Res., Sect. B, Ottawa, :16:341-344, 1938 . 
14 - HORWITZ, W. - Official methods of analysis of the Associa tion of Official Analytical Chemists. Il.ed. Washington, Association of Official Analytical Chemists,1970 p.858.

15 - HYDOVITZ, J.D. - Occurence of goiter in an infant on soy diet. 'New Ergl.'T.Med., Boston, 262:351-353. 1960.

16 - IKEDA, E.; NICOLAU, W.; MURAMOTO, E.; MARQUES DE ASSIS,L.; PIERONI, R.R. - Separação de compostos iodados bilia res e fecais por filtração em Sephadex G-25 M. Estudo do metabolismo entero-hepätico da 125-1-tiroxina. Rev. - Ass.méd.brasill., São Paulo, 19:131-136, 1973.

17 - INTERNATIONAL DEVELOPMENT RESEARCH CENTER - Summary of the general discussion on chronic cassava toxicity, Ottawa, 1973, P. $159-162$.

18 - JENEY, E. - New date of pharmacology of flavonoids. "Acta physiol.Acad.Sci.hung., Budapest, :34:193-212, 1968.

19 - KONIJN, A.M.; EDELSTEIN, S.; GUGGENHEIN, K. - Separation of a thyroid-active fraction from unheated soya bean flour. 'J.Sci.Food Agric., London,: 23:549-555, 1972 .

20 - KONIJN, A.M.; GERSHON, B.; GUGGENHEIM, K. - Further purification and mode of action of a goitrogenic material from soybean flour. 'J.Nutr., Philadelphia, $103: 378-383,1973$. 
21 - LAJOLO, F.M. - Estưdo bromatolögico de concentrados protëicos de Sardinella aurita e de Tilapia metanopleura ob-

tidoos por extraçāo com isopropanol. São Paulo, 1969 . [Tese - Faculdade de Farmácia e Bioquímica].

22 - LEONARDS, J.R. - Correlation between results of a new T-3 test and the percentage of free thyroxine in serum. 'Clin.Chem., New York, :16:922-924, 1970.

23 - LIENER, I.E. - Legume toxins in relation to protein digesti bility - A review. 'J.Food Sci., Chicago, :41:1076-1081, 1976.

24 - LIENER, I.E. \&AKADE, M.L. - Protease inhibitors. In: LIE NER, I.E. Toxic Constiturents of pian't foodstuffs. New York, Academic Press, 1969, p.7-68.

25 - LINAZASORO; J.M.; SANCHEZ-MARTIN, J.A.; JIMENEZ-DIAZ, C. - Goitrogenic effect of walnut and its action on thyroxine excretion. 'Endocrinology, Springfield, ::86: $696-700,1970$.

26 - MANTEL, N. - Rapid stimation of standard errors of small samples. 'Amer.Stati'st., Washington, $5: 26-27,1951$.

27 - MCCARRISON, R. - The goitrogenic action of soya-bean and ground-nut. 'Iridian: J.Med.Res., Punjab;:21:179-181, 1933. 
28 - MCLAREN, G.A.; ASPLUNP, R.0.; CROW, D.G.; TSAI, L. I., PORTERFIELD, I.D. - Influence of dried-grass silage and silage fractions on basal metabolic rate of rats. J.Nutr., Philadelphia: :83:218-224, 1964 .

29 - MOUDGAL, N.R.; RAGHUPATHY, E.; SARMA, P.S. - Studies on goitrogenic agents in food. III. Goitrogenic action of some glycosides isolated from edible nuts. ' J. Nurtr., Philadelphia: :66:291-303, 1958 .

30 - NORDSIEK, F.W. - Effects of added casein on goitrogenic action of different dietary levels of soybeans. 'Proc. -Soc.'exp'Biol., New York,: 1210:417-420, 1962.

31 - OGINSKY, E.L.; STEIN, A. E.; GREER, M. A. - Myrosinase activity in bacteria as demonstrated by conversion of progoitrin to goitrin. 'Proc.Soc.'exp.Biol., New York, : 199 : 360-364, 1965 .

32 - PAXMAN, P.J. \& HILL, R. - The goitrogenicity of kale and its relation to thiocyanate content. - j.Sci.Food Agric., London,: 25:329-337, 1974 .

33 - PINCHERA, A.; MacGILLIVRAY, M. H.; GRAWFORD, J. D. ; FREEMAN, A.G. - Thyroid refractorines in an athyreotic cretin fed soybean formula. 'New Erigl:. U. Med., Boston, :273:83-87, 1965 . 
34 - QUASIM, S.A. \& STELZIG, D.A. - Stimulation of basal metabolic rate of rats fed dried-grass silage and silage flavonoids.' J.Mutr., Philadelphia: 103: 1658$1664,1973$.

35 - REILLY, W.A.; SCOTT, K.G.; WHITE, W.E. - Increase uptake of iodine-131 by the thyroid gland after administration of hesperidine methyl chalcone. 'Proc.Soc.'9xp'. -Biol., New York, :81:682-683, 1952.

36 - SAGHIR, A.R.; COWAN, J.W.; SALJI, J.P. - Goitrogenic activity of onion volatiles. Nature, London,:2ll: 87 , 1966.

37 - SALVATORE, G.; GOVELLI, I.; ROCHE, J. - La fixation des hormones thyroidiennes par Escherichia coli. e son mécanisme. 'Gen'.comp.Erdơor., New York; 3:15-25, 1963.

38 - SAMBETH, W.; NESHEIM, M.C.; SERAFIN, J.A. - Separation of soybean whey into fractions with different biological activities for chicks and rats. 'J.Nutr., Philadelphia, $: 92: 479-490,1967$.

39 - SCHINGOETHE, D.J.; AUST, S.D.; THOMAS, J.W. - Separation of mouse growth inhibitor in soybeans from trypsin inhi bitors. J.Nutr., Philadelphia, :100:739-748, 1970. 
40 - SCHINGOETHE, D.J.; TIDEMANN, L.J.; UCKERT, J.R. - Studies in mice on the isolation and characterization of growth inhibitors from soybeans: J.Nhrtr., Philadelphia, $: 104: 1304-1312,1974$.

41 - SCOTT, A.J. \& KNOTT, M. - A cluster analysis method for grouping means in the analysis of variance. Biometrics, Tallahasee; :30:507-512, 1974.

42 - SCOTT, K.G. \& STREI, L. - Effect of bioflavones upon metabolism of lodine and iodinated compounds in the rat. 'Proc.Soc.exp.'Biol., New York: :84:493-497, 1952.

43 - SEIKEL, M.K. - Chromatographic methods of separation, isolation and identification of flavonoid compounds. In: GFISSMAN, T.A. - The 'chemistry of flavorid compounds. New York, MacMillan, 1962. p.35-69.

44 - SHARPLESS, G.R.; PEARSONS, J.; PRATO, G.S. - Production of goiter in rats with raw with treated soy bean flour. 'J.Nutr., Philadelphia: 17:545-555, 1939.

45 - SHEPARD, T.H.; PYNE, G.E.; KIRSCHVINK, J.F.; MCLEAN, M. C. - Soybean goiter: report of three cases. "New Engl. - J.Med., Boston, :62:1099-1103, 1960 .

46 - SOCOLOW, E.L. \& SUZUKI, M. - Possible goitrogenic effects of selected japanese foods. 'J.Nutr., Philadelphia,83: 20-26, 1964 . 
47 - SPIES, J.R. - Calorimetric procedures for amino acids. - Meth. Enzimol. New York: $3: 468-471,1957$.

48 - VAN ETTEN, C.H. - Goitrogens. In: LIENER, I.E. - Toxic - constituents of plant foodstuffs. New York, Academic Press, 1969. p.103-142.

49 - VAN MIDDLESWORTH, L. - Thyroxine excretion, a possible cause of goiter. 'Endocrinology, Springfield;:61:570573,1957 .

50 - VAN WYK, J.J.; ARNOLD, M.B.; WYNN, J.; PEPPER, F. - The effects of a soybean product on thyroid function in humans: 'Pediatrics, Springfield,: 24:752-760, 1959 .

51 - VANDERLAAN, W.P. \& CAPLAN, R. - Observation on a relation ship between total thyroid iodine content and the iodi de-concentrating mechanism of the thyroid gland fo the rat. Endoocrinology, Springfield;:54:437-477, 1954.

52 - VILLELA, G.G.; BACILA, M.; TASTALDI, H. - Técrícas e - experimentos de bioquínica. Rio de Janeiro, Guanabara Koogan, 1973, p.136.

53 - WILGUS, JR,.H.S.; GASSNER, F.X.; PATTON, A.R.; GUSTAVSON, R.G. - The goitrogencity of soybeans. 'J.Nurtr., Philadelphia: :22:43-52, 1941 . 
54 - WILLS JUNIOR, J.H. - Goitrogens in foods. In: TOXICANTS Ocurring naturally in foods. Washington, National Academy of Science, 1966. p.3-17.

55 - WOEBER, K. A. \& INGBAR, S. H. - Antitbyroid effect of noncalorigenic congeners of salicylate, with observations on the influence of serum protein on the potency of antithyroid agents. 'Endocrinology, Sprin field: $: 76: 584-590,1965$.

56 - WOLF, W.J. \& COWAN, D. - Soybean as a food source. 'Crit. - Rev. Food Tecriol., Cleveland; :22:81-158, 1971.

57 - WOLFF, J. - Transport of iodide and other anions in the thyroid gland." Physiol:Rev., Washington: $: 44: 45-90$, 1964.

58 - YAMADA, T.; KAJIHARA, A.; TAKEMURA, Y.; ONAYA, T. - Anti tryroid compounds. In: GREIGER, S.R. ed.; Harrabook of - plrysiologgy. Washington, American Physiological Society, 1974. Sec.7, v.3, p.345-357. 
Soybean derivatives were tested in rat through acute experiments of 3 to 24 hours and two semichronic experiments of 16 and 29 days.

The acute essay were realized with Total Extracts (TEs) obtained from Defated Soybean Flour (DSF) by precipitation in an aquous medium ( $\mathrm{pH} 4,2)$ and posteriorly in acetone (2 vol.). It was observed that the Total Autoclaved Extract (TAE) administered by gastric tube after 6 and 24 hours decreased the percentage of iodine $\left({ }^{13 I_{I}}\right.$ ) uptake by $100 \mathrm{gr}$. of rat. The Total Extract, without previous autoclaving showed effect on the gland after 6 hours and lost its activity 24 hours after its administration.

TEs obtained from Comercial Soybean Products as: Proteic Concentrate, Tosted Flour and Milk also provoked a decrease in percentage of iodine $\left({ }^{13 I_{I}}\right.$ ) uptake after 24 hours by $100 \mathrm{gr}$. of rat.

The semichronic experiments were realized with soybean fraction products, which were incorporated to experimental diet. The first semichronic essay of 16 days, showed a reduction in percentage of iodide $\left({ }^{13 I} \mathrm{I}\right)$ uptake by $10 \mathrm{mg}$ of thyroid and an increase of the triiodothyronine-binding capacity of rat serum. In the second semichronic of 29 days, we had an increase in the percentage of iodine ( ${ }^{13 I_{I}}$ ) uptake by $10 \mathrm{mg}$ of thyroid caused by the factor in study and no alteration of seric hormones. We also assayed the thyroid hormones and their precursors in this essay and observed an increase of monoiodotyrosine (MIT), triiodothyronine $\left(\mathrm{T}_{3}\right)$ and thyroxine $\left(\mathrm{T}_{4}\right)$ and a decrease of diiodotyrosine (DIT) and inorganic iodine. We also observed, and increase in the MIT/DIT ratio and decrease in $\mathrm{T}_{3} / \mathrm{T}_{4}$ ratio.

In preliminary physicoohemical tests, the fraction sephadex G-25 showed a positive reaction for ninhidrin, Molish and flavonoids. 
I Grupos experimentais e frações de soja testadas

II Teor de proteína das rações

III Extrato Total, ação após 24 horas

IV Extrato Total, ação após 24 horas (repetição)

$V$ Extrato Total, ação apōs 3, 6 e 24 horas

VI Extrato Total Autoclavado, ação após 24 horas

VII Extrato Total de Farinha de Soja Desengordurada e Autoclavada, ação após 6 horas 42

VIII Extrato Total Autoclavado, ação apōs 6 e 24 horas 43

IX Fracionamento do Extrato Total com etanol $90 \% \quad 49$

$X$ Fracionamento do Extrato Total em Sephadex G-25 52

XI Fracionamento do Extrato Total emsephadex G-25 (repetição)

XII Testes físico-químicos (frações Sephadex G-25) 56

XIII Extratos Total, ação apōs 24 horas (repetição) 58

XIV Produtos Comerciais ou Soja 60

XV 1: ensaio semicrônico, efeito na tireóide e no crescimento

XVI 2: ensaio semicrônico, efeito na tireóide e no crescimento

XVII 20 ensaio semicrônico, efeito na sintese dos hor mônios tireóidiarios

FIGURAS

1 Fracionamento da Farinha de Soja Desengordurada 18

2 Temperatura $x$ autoclavagem $2 I$

3 Cromatografia (iodotirosinas) 27

4 Cromatografia (iodotironinas) 28

5 Extrato Total e Extrato Total Autoclavado x Tempo 44

6 Espectro de absorção (Extrato Total, Sobrenadante

7 Diagrama de eluição Extrato Total (coluna de Sephạ $\operatorname{dex} G-25$ )

8 Espectro de absorção (fração II Sephadex G-25) 